\title{
Use of Perfusion Bioreactors and Large Animal Models for Long Bone Tissue Engineering
}

\author{
Leandro S. Gardel, PhD, ${ }^{1-4}$ Luís A. Serra, PhD, ${ }^{5}$ Rui L. Reis, PhD, ${ }^{1-3}$ and Manuela E. Gomes, PhD ${ }^{1-3}$
}

Tissue engineering and regenerative medicine (TERM) strategies for generation of new bone tissue includes the combined use of autologous or heterologous mesenchymal stem cells (MSC) and three-dimensional (3D) scaffold materials serving as structural support for the cells, that develop into tissue-like substitutes under appropriate in vitro culture conditions. This approach is very important due to the limitations and risks associated with autologous, as well as allogenic bone grafiting procedures currently used. However, the cultivation of osteoprogenitor cells in 3D scaffolds presents several challenges, such as the efficient transport of nutrient and oxygen and removal of waste products from the cells in the interior of the scaffold. In this context, perfusion bioreactor systems are key components for bone TERM, as many recent studies have shown that such systems can provide dynamic environments with enhanced diffusion of nutrients and therefore, perfusion can be used to generate grafts of clinically relevant sizes and shapes. Nevertheless, to determine whether a developed tissue-like substitute conforms to the requirements of biocompatibility, mechanical stability and safety, it must undergo rigorous testing both in vitro and in vivo. Results from in vitro studies can be difficult to extrapolate to the in vivo situation, and for this reason, the use of animal models is often an essential step in the testing of orthopedic implants before clinical use in humans. This review provides an overview of the concepts, advantages, and challenges associated with different types of perfusion bioreactor systems, particularly focusing on systems that may enable the generation of critical size tissue engineered constructs. Furthermore, this review discusses some of the most frequently used animal models, such as sheep and goats, to study the in vivo functionality of bone implant materials, in critical size defects.

\section{Introduction}

$\mathbf{T}$ He TISSUe ENGINEERING AND REgenerative medicine (TERM) field has expanded rapidly as new discoveries are made that render possible tissue replacement and regeneration. Considering the body's tissues biochemical, biophysical and hydrodynamic requirements, functional tissue engineering requires the development of new tools for in vitro tissue culture, to create a biotissue that can develop in vivo, and replace damaged tissue. ${ }^{1,2}$ Moreover, the increasing patient demand for tissue-engineered products and therapies requires technologies for large scale production of tissue substitutes with precise control of shape/size and high quality. $^{3-6}$ Bioreactors can be defined as devices in which biological or biochemical processes, or both, are re-enacted under controlled conditions (for example, $\mathrm{pH}$, temperature, pressure, oxygen supply, nutrient supply, and waste removal). Originally most bioreactors were developed to test biomaterials but some of them were also invented with the objective of enabling extracorporal tissue growth. ${ }^{7}$ In fact, bioreactors might facilitate the aseptic growth of functional tissues and simultaneously offer several further advantages over culture in plates and flasks. ${ }^{8,9}$ In addition, bioreactors can be custom designed for engineering tissues with complex three-dimensional (3D) geometry containing multiple cell types. ${ }^{10}$ The fact that physical stimuli can modulate cell function and tissue development has further motivated the development of biomechanically active stimulation systems to culture functional cell-tissues constructs in vitro by exposing them to physiologically relevant mechanical and/or hydrodynamic stimulation. The overall goal is to have systems that reliably and reproducibly form, store, and deliver

\footnotetext{
${ }^{1}$ 3B's Research Group-Biomaterials, Biodegradables and Biomimetics, University of Minho, Headquarters of the European Institute of Excellence on Tissue Engineering and Regenerative Medicine, Guimarães, Portugal.

${ }^{2}$ Department of Polymer Engineering, University of Minho, Headquarters of the European Institute of Excellence on Tissue Engineering and Regenerative Medicine, Guimarães, Portugal.

${ }^{3}$ ICVS/3B's PT Govermment Associated Lab, Braga, Portugal.

${ }^{4}$ Department of Clinic Veterinary, ICBAS-University of Porto, Porto, Portugal.

${ }^{5}$ Department of Ortophysiatric, General Hospital Santo António, Porto, Portugal.
} 
functional tissues substitutes that can sustain function in vivo. In essence, the bioreactor needs to provide the appropriate physical stimulation to cells, continuous supply of nutrients (e.g., glucose, amino acids), biochemical factors, and oxygen, diffusion of chemical species to the construct interior, as well as continuous removal of by-products of cellular metabolism (e.g., lactic acid). ${ }^{11}$ In the absence of a vascular blood supply in vitro, nutrient delivery to cells throughout 3D tissue-engineered constructs grown in static culture must occur by diffusion. As a result, thin tissues and tissues that are naturally avascular (e.g., cartilage) have been more readily grown in vitro than thicker, vascular tissues, such as bone. ${ }^{12-14}$ The ex vivo generation of larger 3D tissue substitutes particularly requires the development of enlarged devices and systems that allow cells to distribute within a wide 3D space, and at the same time satisfy the physicochemical demands of culturing such large cell masses into a scaffold. ${ }^{6,15}$ Several international research groups have demonstrated the advantages of using culture systems that combine both hydrodynamic and mechanical stimulation during tissue development. ${ }^{16-21}$ The vast majority of these studies report on the development and use of perfusion bioreactors, which are mostly composed of a perfusion pump with one or more output channels where the flow can be controlled and connected to single or multiple cell culture chambers through silicone tubes, which allow the exchange of gases $\left(\mathrm{O}_{2}, \mathrm{CO}_{2}\right)$ between the culture medium and the environment. Most of these groups work for the development of new combinations of stem cells and materials constructs to obtain functional tissue-engineered constructs for bone regeneration. Thus, they are also interested in developing and evaluating their concepts in highly reproducible large segmental defects in preclinical large animal models. These studies should allow the development of methods to produce reliable data (biocompatibility, mechanical stability, and safety), creating a real set of information to allow, in the near future, the use of tissue engineered constructs of large dimensions, specifically translating into the orthopedics surgical field. This is an essential step in the process of assessing newly developed bone grafts before clinical use in humans. Animal models allow the evaluation of materials in loaded or unloaded situations over potentially long time durations and in different tissue qualities and ages. While some animal models may closely represent the mechanical and physiological human clinical situation, it must be remembered that it is only an approximation, with each animal model having unique advantages and disadvantages. ${ }^{22}$ This review examines the existent literature concerning the use of perfusion bioreactors systems and large animal models to evaluate tissue engineered constructs of large dimensions.

\section{Bioreactors for Bone Tissue Engineering}

For tissue engineering purposes, dynamic culture bioreactors, such as spinner flasks, ${ }^{23,24}$ rotating wall bioreactors, ${ }^{23,25}$ and flow perfusion systems, ${ }^{19,26}$ have shown promising results. In general, dynamic culture yields a much more homogeneous distribution of cells and matrix, while systems enabling shear stresses applied by the medium flow may stimulate the cells to proliferate and differentiate. Furthermore, these systems enhance mass transport, ensuring continuous nutrition of cells, and removal of waste products.
The commonly used spinner flasks are low cost equipment, but the nonuniform media flow that is provided around scaffolds limits their use. The cells on the outer periphery of scaffolds are subjected to a turbulent flow, whereas the cells in the interior rely on diffusion for nutrient transport. ${ }^{27} \mathrm{Si}-$ milar drawbacks are seen in the rotating wall bioreactor. In these bioreactors, the use of scaffolds with different architectures leads to the generation of internal shear stresses of different magnitudes, eventually leading to the localized generation of extremely high shear forces, with negative effects in the cells. Some flow perfusion systems overcome the flow issues because medium is flushed directly through scaffolds, ${ }^{19,26}$ thereby providing nutrient and stimuli throughout the entire volume of the scaffold. ${ }^{27}$ The design and performance of bioreactors is therefore, of special relevance in recent and future tissue engineering strategies. Bioreactors that use a pump system to perfuse media directly through a scaffold are known as perfusion bioreactors. ${ }^{28}$ Perfusion bioreactors with defined mechanical stimulation functions are of special interest to optimize the ex vivo growth of the desired cell or scaffold constructs. ${ }^{7,29}$ However, direct perfusion introduces a new level of complexity when scale-up is considered, and the engineering challenges may be significant. ${ }^{11}$

Nutrition, chemotransport enhancement, and mechanical stimulation (dynamic tension, compression, or hydrodynamic forces) of cells or cell/scaffold constructs, control over environmental conditions, culture duration, on-line evaluation of biological variables, and automation of bioprocesses should be considered for the development and use of bioreactors. ${ }^{1,29-35}$ Moreover, bioreactors should to be able to operate over long periods of time under aseptic conditions since maturation of a functional tissue substitute may take up to several weeks. Another important issue in the design of bioreactors is the monitoring of tissue growth. In fact, an advantage in the area would be the development and employment of techniques, which could assess the integrity of the tissue noninvasively. ${ }^{11}$ Oxygen and nutrient need and its consumption by the cells, metabolite removal and fluid flow within the site have a dramatic impact on the growth and survival of enlarged constructs for tissue substitution, and when controlled can be used as major positive modulators in elaborated bioreactors. This would allow for a higher efficiency in the tissue engineering process, as well as a high degree of certainty in obtaining grafts within the predetermined manufacturing specifications.

\section{Perfusion bioreactors}

In addition to enhancing mass transport, perfusion bioreactors systems may be used to deliver controlled mechanical stimuli, such as flow-mediated shear stresses and/ or hydrodynamic forces to tissue constructs. ${ }^{36-38}$ Different perfusion bioreactor have been developed but most systems consist of a similar basic design consisting of a media reservoir, a pump, a tubing circuit, and perfusion chambers, columns or cartridges that hold the cell/scaffold constructs. ${ }^{39}$ Perfusion bioreactor systems have been developed to culture a variety of shapes and sizes of $3 \mathrm{D}$ bone tissue constructs. ${ }^{19,25,40-54}$ In these systems, it is obvious that the flowrate used for the medium perfusion is responsible to a great extent for the effects in the microenvironment of cells, that is, 
for the magnitude of the shear stress sensed by the cells. Porter et al. (2005) estimated the local shear stresses inside 3D natural scaffolds using the lattice Boltzmann method (LBM) for cell culture media flow through trabecular bone, performing reconstructions using microcomputed tomography $(\mu \mathrm{CT}) .^{55}$ Based on this study, $\mu \mathrm{CT}$ has been used in conjunction with fluid dynamics simulations, to characterize the distribution of shear stresses within 3D scaffolds. ${ }^{56,57}$ Nevertheless, the local internal shear stress created by perfusion systems using hydrodynamic forces and experienced by the cells on 3D matrices, is influenced not only by the medium flow rate but also by other parameters that have to be considered, for example, the porosity, the dimensions, the material and the geometry of the scaffold, ${ }^{58}$ as well as the existence of manufacturing defects that create areas of high flow and high stress along the periphery of the scaffold ${ }^{56}$ the size, the anisotropy, and the degree of interconnectivity of pores, as well as the viscosity of the medium. ${ }^{58}$

Nowadays, multidisciplinary efforts are being made to improve the size and quality of the bone substitutes that can be obtained in vitro. These efforts focus on the cell types used, scaffold structure/composition, and also on the cultivation in perfusion bioreactor systems with various designs. However, most studies on perfusion bioreactors describe systems that only enable culturing small scaffolds, which do not meet clinically relevant constructs size in the field of orthopedics defects regeneration. In the following sections, the main differences between two basic types of perfusion bioreactors (with individual culture chambers and single culture chamber), which enable to culture scaffolds with different dimensions, are described and discussed in the light of the current clinical need for larger engineered bone substitutes.

Perfusion bioreactors with individual culture chambers for culturing small dimension constructs. In flow perfusion systems composed of individual chambers, usually the scaffolds are fitted in the culture chambers so that media cannot flow around it; thus, perfusing media directly through the pores of the scaffold. The flow of medium through the scaffold porosity benefits cell differentiation by enhancing nutrient transport to the scaffold interior, and by providing mechanical stimulation in the form of shear stresses. ${ }^{49,55,59}$ In fact, studies with perfusion systems have suggested that flow has many biological effects, ${ }^{27,60-63}$ such as prostaglandin E2 release, ${ }^{64}$ osteogenic differentiation enhancement, ${ }^{49}$ and mineralized matrix production increase on bone marrow stromal osteoblasts seeded in 3D scaffolds. ${ }^{65}$ Research works using either custom-made or commercially available perfusion bioreactor systems are specified in the Table 1.

In 2001, Goldstein et al. ${ }^{25}$ compared a perfusion flow bioreactor to other systems that promote media convection, namely a spinner flask and a rotary vessel. For this purpose, they used poly (DL-lactic-co-glycolic acid) (PLGA) foam discs seeded with marrow stromal cells and cultured in the presence of dexamethasone and L-ascorbic acid, at a constant flow rate. Cell numbers per foam were found to be similar with all culturing systems indicating that cell growth could not be enhanced by convection, but histological analysis indicated that the rotary vessel and the flow system produced a more uniform distribution of cells throughout the foams.
Alkaline phosphatase (ALP) activity per cell was higher with culture in the flow system and spinner flask after 7 days, while no difference in osteocalcin (OC) activity per cell was observed among culturing methods after 14 days. Based on these results, the flow system appears to be the superior culturing method. ${ }^{25}$

In 2002, Bancroft et al. ${ }^{65}$ reported the development of another flow perfusion bioreactor and investigated the effect of different flow rates, in rat bone marrow cells seeded into titanium fiber mesh scaffolds cultured in osteogenic media. Culturing seeded scaffolds at different flow rates for 16 days revealed a dose-dependent effect of flow perfusion rate on mineralized matrix production, matrix modeling, and cell matrix distribution. The latter was significantly higher in the flow perfusion cultures when compared with static culture. ${ }^{65}$ van den Dolder et al., in $2003{ }^{63}$ used the same bioreactor, biomaterial, culture medium and cells, to analyze the effect of flow perfusion (as compared to static conditions), at a constant flow rate, founding that this system can enhance the early proliferation, differentiation, and mineralized matrix production of rat bone marrow stromal cells. ${ }^{63}$

The same bioreactor developed by Bancroft et al., in $2002,{ }^{65}$ was used in other studies, using different types of scaffolds, such as porous biphasic calcium phosphate ceramic scaffolds, ${ }^{49}$ poly(L-lactic acid) nonwoven fiber mesh scaffolds, ${ }^{43}$ and starch polycaprolactone (SPCL) biodegradable fiber mesh scaffolds. ${ }^{40,41}$ Furthermore, Holtorf et al., in $2005,{ }^{66}$ showed that using this system, even in the absence of dexamethasone supplement, rat BMSCs can differentiate into osteoblastic. ${ }^{66}$ Gomes et al., in $2003^{40}$ have also showed that rat BMScs proliferation and differentiation are affected by the scaffold's porosity and architecture ${ }^{40}$ and reported increased production and localization of TGF- $\beta 1$, VEGF, BMP-2, and FGF-2 in constructs cultured under increase fluid flow rate. ${ }^{41}$ Based on the same bioreactor design, Alvarez-Barreto et al., in $2007,{ }^{67}$ developed and characterized an oscillatory flowperfusion seeding technique, to improve seeding efficiency, cell spatial distribution and strength of cell adhesion. The technique consisted in the application of an oscillating flow for $2 \mathrm{~h}$ at $0.1 \mathrm{~mL} / \mathrm{min}$ that is created by manually changing the direction of the pump every $5 \mathrm{~min} .{ }^{67}$ This technique led to enhanced seeding efficiency and osteoblastic differentiation of rat BMSC cultured in poly (glycolic acid) (PGA) scaffolds. ${ }^{68}$ Bjerre and coworkers in $2008,{ }^{69}$ performed another modification of the same bioreactor. The modified system consists of 16 parallel flow chambers, each supplied by a common reservoir controlled by a peristaltic pump. They analyzed the proliferation and differentiation of hMSC cultured on silicate-substituted tricalcium phosphate (TCP) scaffolds at a constant flow rate as compared to static culture. Data obtained from ALP activity and RT-PCR analysis of bone markers after 14 days in flow culture demonstrated an increase in proliferation, differentiation and cell/matrix deposition. ${ }^{69}$

The perfusion bioreactor from Minucells and Minutissue ${ }^{\circledR}$, are one of the few commercially available culture systems and has a different design: there is not a recirculation of the culture medium as in most systems described; the culture medium is perfused through 12 culture chambers in one direction, each in a thermo plat $\left(37^{\circ} \mathrm{C}\right)$ in room temperature, connected to another bottle (waste culture medium) where the flow ends. This system was used by Wang et al., in 


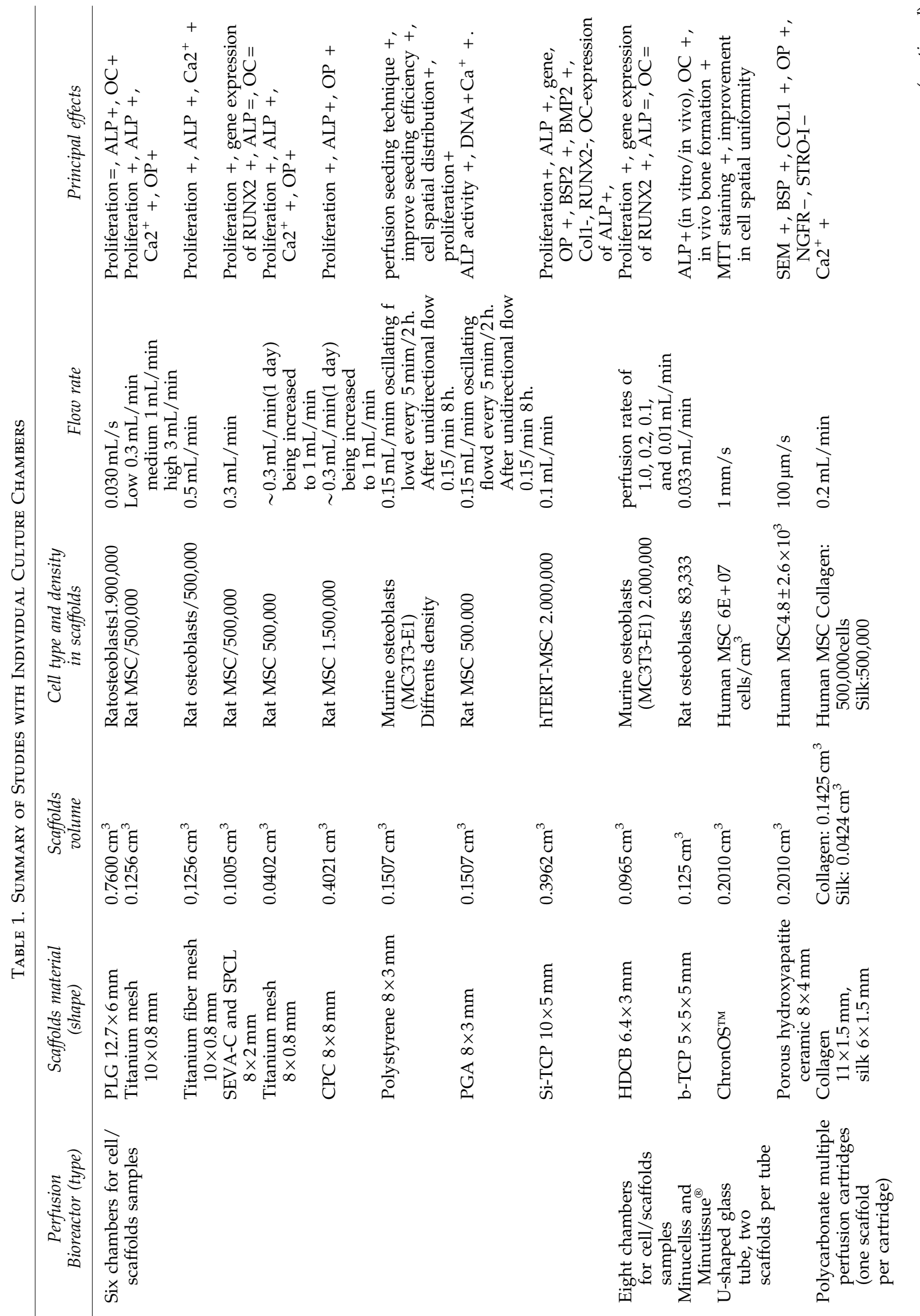

है

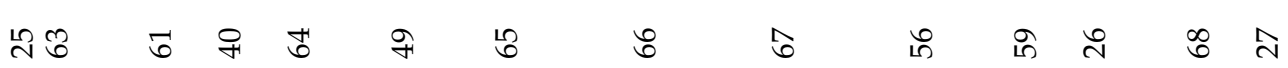




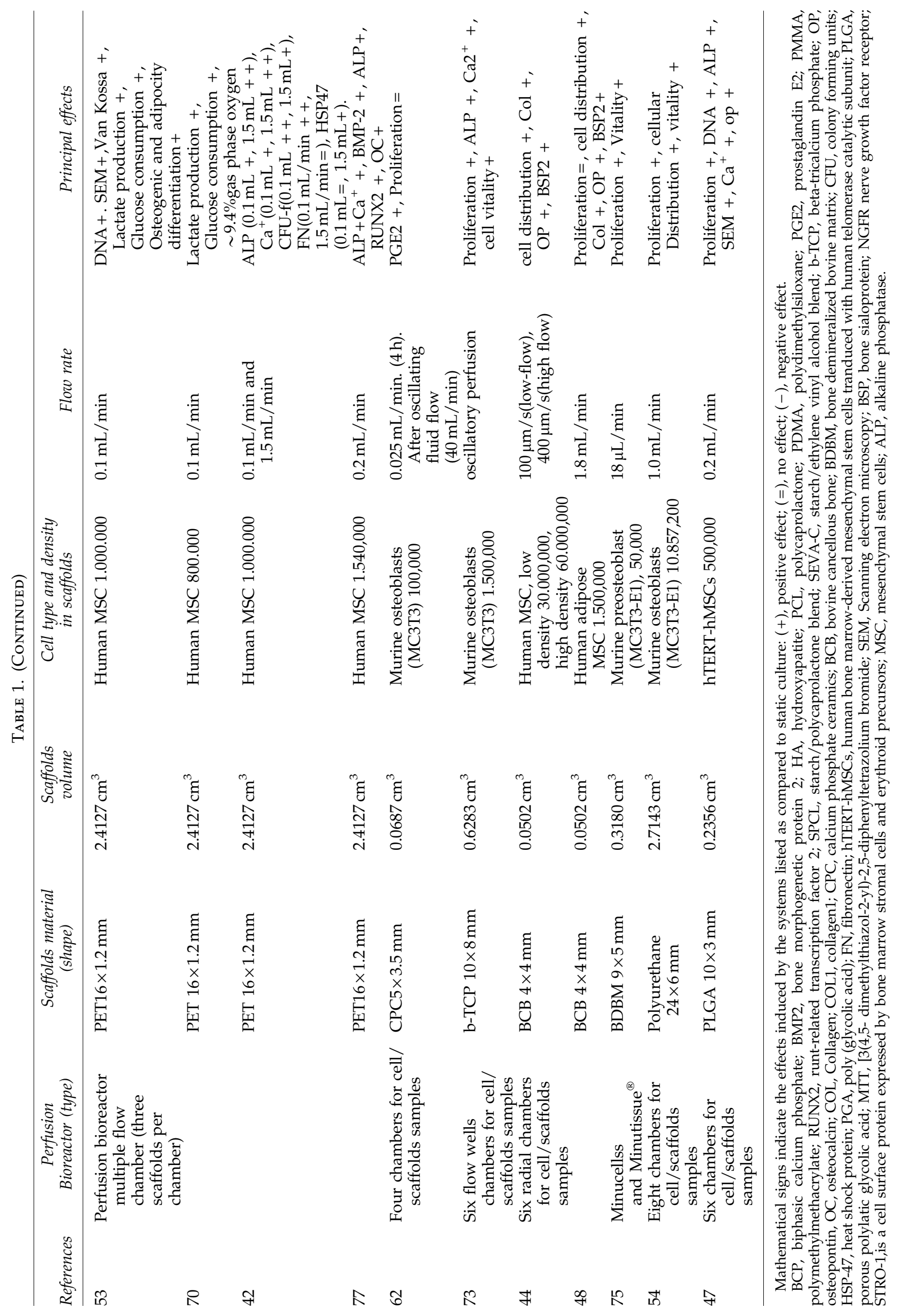


$2003,{ }^{61}$ to culture bone marrow-derived cell in porous ceramic scaffolds, using a constant flow rate. ALP and OC expression were increased in perfusion cultures when compared of static cultures. ${ }^{61}$

Wendt et al., in $2003^{26}$ developed a bioreactor for automated cell seeding of 3D scaffolds by continuous perfusion of a cell suspension through the scaffold pores in oscillating directions. In this system, scaffolds are placed in chambers (one scaffold per chamber) that are positioned at the bottoms of two glass columns and connected through a U-shaped glass tube at their base. Flow is induced with the use of a vacuum pump and the flow rate regulated with a flow meter. The direction of flow is reversed when the fluid level in one column reaches an optical sensor placed near the top of each glass column. The sensor detects the cell suspension, actuating a pair of solenoid valves, switching the vacuum to the opposite column, and therefore, reversing the direction of fluid flow. To assess the efficiency and uniformity of perfusion seeding of Polyactive foams ChronOS $^{\circledR}$ seeded with bone marrow stromal cells (BMSCs), as compared to static and spinner flask cultures, they used quantitative biochemical and image analysis techniques. The results showed that perfusion seeding of cells into Polyactive foams were more homogeneously distributed throughout the scaffold volume and formed more homogeneously sized cell clusters when compared to other systems. ${ }^{26}$ Braccini et al., in $2005,{ }^{70}$ used the same system, to study the effect on seeding, expansion, and differentiation of BMSCs into a 3D hydroxyapatite scaffolds and subsequent in vivo outcomes. When implanted ectopically in nude mice, the engineered constructs generated bone tissue more reproducibly, uniformly, and extensively than scaffolds loaded with 2D expanded BMSCs. ${ }^{70}$

Zhao and $\mathrm{Ma}$, in $2005,{ }^{53}$ modified a 3D perfusion bioreactor system developed previously by Ma et al., in $1999,{ }^{71}$ which is composed of three circulating loops. The main circulating loop includes culture chambers and a section of the flow path for continuous circulation of medium. The inoculation loop includes culture chambers and a section of the flow path used for inoculating cells into scaffolds. The replenishing loop consists of the fresh media container and the section of the flow path used for supplying fresh media to the system. The two inlets and two outlets in each chamber are connected to independent inlets from the computerized peristaltic pump that has eight independent channels. This system enables the recirculation of media and has two sampling ports at the inlet and outlet of each chamber. Furthermore, it can accommodate multiple flow chambers, depending on the operational requirements. To examine the dynamic seeding efficiency, the author used nonwoven poly (ethylene terepthalate) (PET) fibrous scaffolds cultured with human mesenchymal stem cells (hMSC). They observed an inverse correlation between flow rates for seeding operation and seeding efficiencies and analyses showed that after a long period of culture, higher cell densities of hMSCs were found in the bioreactor system. ${ }^{53}$ With the same method and biomaterial Zhao et al., in $2005,{ }^{72}$ studied the effects of the physiological oxygen environment on the intrinsic tissue development characteristics in the 3D scaffolds as compared to static conditions, using mathematical modeling. Results show that the oxygen tension in the static culture is lower compared with the perfusion unit, where the cell density was four times higher. ${ }^{72}$ To demonstrate the effect of shear stress,
Zhao et al., in 2007,42 cultured porous 3D PET matrices with hMSC at different flow rates in the same bioreactor. The higher flow rate enhanced osteogenic differentiation potential at 14 days, and calcium deposition in the matrix after 20 days with osteogenic media. ${ }^{42}$

A perfusion bioreactor was developed by Timmins and coworkers in $2007,,^{73}$ the tissue culture under perfusion (TCUP), based on the concept of controlled and confined alternating motion of scaffolds through a cell suspension or culture medium, as opposed to pumping the fluid through the scaffolds. Different cell types, as well as scaffold designs and compositions were tested. When freshly isolated human bone marrow nucleated cells seeded into ENGipore ${ }^{\circledR}$ ceramic scaffolds cultured for 19 days in the T-CUP resulted in stromal cell-populated constructs capable of inducing ectopic bone formation in nude mice. ${ }^{73}$

Grayson et al., in 2008, ${ }^{44}$ described a bioreactor system that enables cultivation of up to six tissue constructs simultaneously in individual chambers, using a radial channel with direct perfusion and imaging capability. Fully decellularized bovine trabecular bone was used as a scaffold, seeded with hMSCs using different cellular densities and different flow rates (low and high). The results of the study indicated that, at the seeding densities evaluated, greater initial cell numbers do not necessarily result in increased bone formation. The study also showed that flow rate of medium perfusion remains a significant parameter that allows a more uniform tissue development and supports higher cell densities within the constructs. ${ }^{44}$ Frohlich et al., in $2010,{ }^{48}$ using the same bioreactor showed that, human adipose-derived stem cells (hASCs), cultured in decellularized bone scaffolds, after 5 weeks of culture in osteogenic medium, presented significantly increases in the construct cellularity, and in the amounts of bone matrix components. ${ }^{48}$

Costa et al., in 2008, ${ }^{74}$ developed a perfusion bioreactor composed of 20 culture chambers, each one supporting a single, tightly fitting scaffold. A peristaltic pump controls the medium flow rate through the bioreactor, with silicon tubes directly connected to the system and to a medium reservoir (with recirculation flow). Using this system, a study was conducted using SPCL meshes statically seeded with goat bone marrow cells (gBMCs) and cultured in osteogenic medium for 7 and 14 days. The results showed enhanced cellular proliferation and differentiation by combination of fluid flow rate and flow inversion frequency during different culturing periods. ${ }^{74}$ Rodrigues et al. in $2012^{75}$ has further demonstrated the potential of this bioreactor, demonstrating the positive influence of the flow perfusion conditions provided in the osteogenic differentiation of hASC seeded onto SPCL fiber meshes functionalized with Silanol (SI-OH).

An oscillatory perfusion bioreactor was fabricated by $\mathrm{Du}$ et al., in 2008. ${ }^{76}$ The upper chamber consisted of six flow wells custom-machined in a block of Teflon. The base of each well was sealed with a silicon film. The scaffold is pressfitted to a silicon cassette that was then fixed into each well with an upper O-ring and steel cap with up-to-down pressure to ensure that the media would perfuse only through the scaffold and not flow in between the scaffold and cassette or between the cassette and well wall. The lower chamber is filled with sterilized water using a $30-\mathrm{mL}$ syringe with gas removed from the gas outlet. The movement of the syringe back and forth is controlled by a continuous cycle syringe 
pump, forcing the silicon membranes to move up and down; thus, driving the media in the flow wells to perfuse up and down through the scaffolds in an oscillatory manner. Results obtained with a mouse immature osteoblast-like cell line, MC 3T3- E1 seeded in porous beta-TCP (b-TCP) scaffolds suggested that the oscillatory flow condition not only allows a better seeding efficiency and homogeneity, but also facilitates uniform culture and early osteogenic differentiation. ${ }^{76}$ The same group designed a unidirectional perfusion system. A media bottle is set on each end of the perfusion chamber as both media reservoirs and gas bubble trappers. A gas-permeable bag is set in the circuit loop as a gas exchanger. The unidirectional media flow was driven by a pump. A couple of silicon tubes led from bottle 2 to the clean bench, so that the medium could be exchanged in a sterile environment without moving the whole complicated system. This system presents a recirculation flow; thus, media are drawn from the media reservoir, pumped through the compartments, merged at the outlets of the chambers, and returned back to the media reservoir. The perfusion system with the scaffolds set inside is sterilized by ethylene oxide gas. To compare these two different types of perfusion systems developed; mouse osteoblast-like MC 3T3-E1 cells were 3D-cultured with porous ceramic scaffolds for 6 days under static and hydrodynamic conditions with either a unidirectional or oscillatory flow. In perfusion culture with the unidirectional flow, the proliferation was significantly higher than in the other groups but was very inhomogeneous. Only the oscillatory flow allowed osteogenic cells to proliferate uniformly throughout the scaffolds, and also increased the activity of ALP. ${ }^{35}$

Sailon et al., in $2009,{ }^{54}$ developed a flow perfusion chamber bioreactor with eight individual chambers to provide chemotransportation in thick scaffolds. Polyurethane scaffolds, seeded with murine preosteoblasts, were cultured. Flow-perfused scaffolds demonstrated increase in peripheral cell density and core density at day 8 . This study established that thick $(>6 \mathrm{~mm})$ 3D constructs are sustainable using a flow-perfusion bioreactor. ${ }^{54}$

Yang and coworkers, in 2010, ${ }^{47}$ developed a perfusion system that is composed of six culture cassettes, a multichannel cylinder pump, and a medium reservoir. Each culture cassette contained a screw-top, a neoprene o-ring, and a screw-bottom with an internal cavity. The scaffold is pressfitted on a net in the internal cavity of the screw-bottom. Media flows from top to bottom through the scaffold. Flow through each cassette is driven by the cylinder pump with each culture cassette on its own independent pumping circuit. In the complete perfusion culture circuit, media are drawn from the common media reservoir, pumped through each culture cassette, and returned to the common media reservoir. The entire flow circuit is connected with silicon tubing. Using hMSCs transduced with human telomerase catalytic subunit hTERT (hTERT-hMSCs) cultured in porous PLGA scaffolds under perfusion for 12 days at a flow rate of $0.5 \mathrm{~mL} / \mathrm{min}$, they demonstrated that the flow enhances osteogenic proliferation and differentiation of hTERT-hMSCs, when compared to static conditions. ${ }^{47}$

More recently, Kim et al. in 2011, built an electrical bioreactor, composed of a cylindrical Teflon main part containing a flexible polyimide electrode and an implantable stimulator. The main part has about 300 holes with a diameter of $300 \mu \mathrm{m}$ for medium supply inside the bioreactor and has a length of $17 \mathrm{~mm}$ and a diameter of $8 \mathrm{~mm}$. Upon seeding hMSCs onto collagen sponges (aimed at forming a bone tissue graft), they have cultured the constructs in the bioreactor under biphasic electric current (BEC) stimulation. BEC stimulation with amplitude of $20 / 40 \mu \mathrm{A}$, duration of $100 \mu \mathrm{s}$ and a frequency of $100 \mathrm{~Hz}$ was applied for 1 week in the early periods of culturing. Subsequently, after culturing for an additional week without electrical stimulation, cell response was evaluated in terms of proliferation, attachment and gene expression. In vitro culture of hMSCs under stimulation showed $19 \%$ and $22 \%$ increase in cell proliferation, as compared to unstimulated controls. The expression of type I collagen also increased significantly in the cells submitted to the BEC. The results showed that this electrical bioreactor may enhance the efficiency of stem cell-based tissue engineering ${ }^{77}$ approaches.

To visualize and to examine the effect of shear stress in the a tubular perfusion system (TPS) bioreactor, Yeatts et al. in $2012{ }^{78}$ used hMSCs seeded and cultured into spherical alginate bead scaffolds of two sizes. After 21 days of culture, it was observed a strong correlation of the shear stress in hMSC osteoblastic differentiation indicated by the production of osteopontin, and bone morphogenic protein-2. Further results revealed an approximate 2.5 -fold increase in cell number in the inner annulus of TPS cultured constructs as compared to statically cultured constructs after 21 days. It was also observed a significant increase in mineralization in the inner and outer regions of the beads $(4 \mathrm{~mm})$ scaffolds cultured in the bioreactor on day 21, when compared to those cultured in static conditions. These results demonstrate a relationship between scaffold position and stem cell fate in this bioreactor and further demonstrate also the importance of bioreactor systems in promoting hMSC proliferation and differentiation in 3D scaffolds. ${ }^{78}$

Knapp and coauthors in $2012,{ }^{79}$ built a custom-made bioreactor for bone tissue engineering, where they have cultured a macroporous hydrogels disc-shaped with adiposederived stem cells (ASC), using noninductive ostegenic media (IMDM $+10 \%$ FCS), under pulsatile flow rate conditions. Results demonstrated that dynamic cultures provided a strong osteogenic induction with 100-fold higher levels of ALP and OC mRNA. ${ }^{79}$

Fan et al., in 2012, ${ }^{80}$ cultured tri-calcium phosphate scaffolds (12 $\mathrm{mm}$ in diameter and $10 \mathrm{~mm}$ in height) of different porosities (Low, Medium and High) in static and perfusion conditions using a custom-made perfusion bioreactor. Results demonstrated that higher permeable scaffolds exhibited superior performance and that the advantages of higher scaffold permeability were amplified in the perfusion culture. ${ }^{80}$

Qian et al. in $2013,{ }^{81}$ studied a porous nanohydroxyapatite/polyamide 66 (n-HA/PA66) scaffold with a size of $16 \mathrm{~mm}$ in diameter and $1.5 \mathrm{~mm}$ in thickness, drilling one hole of $2.5 \mathrm{~mm}$ and three holes of $1.5 \mathrm{~mm}$ diameter in the material. The scaffolds seeded with rat bone marrow stromal cells (rBMSCs) were cultured under the static conditions and in a flow perfusion bioreactor. The results showed that values of MTT, ALP, and osteocalcin (OCN) were continuously increased along time in culture and revealed significant higher levels for the group cultured under perfusion conditions. ${ }^{81}$

Nishi et al. in $2013{ }^{82}$ performed a study addressing the issue of vascularization in bone tissue engineering, by coculturing bone marrowMSCs with MSC-derived endothelial 
cells within a porous scaffold composed of D,D-L,L-polylactic acid (cylinder of $5 \mathrm{~mm}$ in diameter and $2 \mathrm{~mm}$ thickness) using a rotating wall vessel (RWV) bioreactor. Overall, the results obtained by histochemical analyzes showed that it was possible to generate a bone-like tissue containing vascular-like structures using a 3D matrix cultures under conditions created by the medium flow in the RWV vessel. ${ }^{82}$

Single culture chamber perfusion bioreactors that enable culturing large sized constructs. As seen in the previous section, many research groups have developed bioreactors that perfuse cell seeded constructs, and that have demonstrated the beneficial effects of perfusion on cell survival, proliferation, differentiation, and extracellular matrix formation in the scaffold. However, these studies focus on the construction of small-size tissue-engineered bone ranging from 0.04 to $2.7 \mathrm{~cm}^{3} .25,27,40,44,48,54,55,59,63-65,69,76,83$ In this section, we will describe some of the available systems that may enable the culture of large dimension constructs.

According to published works there has been an increasing focus on the development of such bioreactors, which are usually designed with a single cellular culture chamber. Hosseinkhani et al., in $2005,{ }^{50}$ developed a perfusion bioreactor in which the cell-seeded scaffolds are set in a sample holder, while the medium flowed by a peristaltic pump at a linear flow velocity to perfuse the medium through the scaffold, using a medium recirculation method and only one medium reservoir. The perfusion system is operated in a $\mathrm{CO}_{2}$ incubator atmosphere. It was found that this system enabled improvement of MSCs proliferation and differentiation in collagen sponges reinforced with PGA fibers. ${ }^{50}$ Furthermore, in another study, it was shown that BMP-2 expression of rat MSCs impregnated with plasmid DNA encoding for BMP-2 was enhanced with perfusion culture. ${ }^{86}$ In a subsequent in vivo study, the collagen-PGA scaffolds of $12 \mathrm{~mm}$ diameter seeded with rat MSCs were implanted ectopically in Fischer male rats. Significant increase in ALP and OC expression at sites of implantation of constructs previously cultured in the perfusion system was observed as compared to constructs obtained in static conditions. ${ }^{87}$

Xie et al., in $2006,{ }^{88}$ described a bioreactor system that is composed of three parts: the driving part, the reservoir, and the tubing part. The driving part consists of up to eight 3-stop tubes, which are fixed in an eight-channel pump head and driven by a peristaltic pump. The reservoir (only chamber) is a $75-\mathrm{cm}^{2}$ flask containing the perfusion medium. In the tubing part, there are two silicone tubes with one end penetrating through the plug cap into the flask as the inlet and outlet. To study the effects of flow shear stress and mass transport, respectively, on the construction of a large-scale tissue-engineered bone substitute, Li et al., ${ }^{45}$ used a critical-sized b-TCP cylinder scaffold $(14 \mathrm{~mm}$ in diameter and $30 \mathrm{~mm}$ in length with a tunnel of the $3.5 \mathrm{~mm}$ in diameter and $25 \mathrm{~mm}$ in length) seeded with hBMSCs. The results suggested that shear stress accelerates osteoblastic differentiation of hBMSCs, while mass transport increases differentiation among lower ranges. ${ }^{45,88}$

A direct semiautomated perfusion bioreactor system (single chamber) was developed by Janssen and his researchers. ${ }^{89}$ Goat bone marrow stromal cells (GBMSCs) were dynamically seeded/cultured in this system in volumes $\left(10 \mathrm{~cm}^{3}\right)$ of small-sized macroporous biphasic calcium phosphate (BCP) scaffolds. Cell load and distribution was shown using methylene blue block staining, and MTT staining was used to demonstrate the viability of the cells. Online oxygen measurements were correlated with proliferating GBMSCs. They conclude that this bioreactor enabled homogenous cell growth of GBMSCs. ${ }^{90}$ In posterior studies, the authors demonstrated that dynamically cultured GBMSCs grown on calcium phosphate ceramic produced bone when implanted into mice. ${ }^{51}$ Another study conducted in 2010 by the same group, concluded that this perfusion bioreactor system is capable of producing clinically relevant and viable amounts of human tissue-engineered bone that exhibit bone-forming potential after implantation in nude mice. ${ }^{89}$

Jaasma et al., in $2008,{ }^{91}$ developed a flow perfusion chamber bioreactor consisting of a syringe pump, a scaffold chamber, and a media reservoir, which are connected via gas-permeable, silicone tubing and tubing connectors. The scaffold is held in place within a silicone O-ring and between two machined polycarbonate pieces. The scaffold is maintained under $\sim 10 \%$ compression using aluminum spacers and an O-ring inner diameter is larger than the flow path diameter through the polycarbonate pieces of the scaffold chamber. The scaffold chamber is designed to accommodate compliant scaffolds, but stiff scaffolds can also be used by adjusting the spacer height. The syringe pump is programmable to allow for the application of steady, pulsatile, and oscillatory flow profiles, and can accommodate up to six 50$\mathrm{mL}$ syringes, which allows for the simultaneous culture of six cell-seeded constructs. The authors used Collagen-GAG (CG) scaffold with $12.7 \mathrm{~mm}$ in diameter and $3.5 \mathrm{~mm}$ of thickness MC 3T3-E1 cells and four scaffolds were cultured simultaneously, but each one in a different bioreactor. Flow analysis revealed that steady, pulsatile, and oscillatory flow profiles were transferred from the pump to the scaffold. Comparing to static, bioreactor culture of osteoblast seeded CG scaffolds led to a decrease in cell number but stimulated an increase in the production of prostaglandin E2, an early-stage bone formation marker. ${ }^{91}$

Another study examined the effect of short term flow perfusion bioreactor culture, before long-term static culture, in the same bioreactor developed by Jaasma et al., in 2008. ${ }^{91}$ Human fetal osteoblasts (hFOB 1.19) were seeded onto CG scaffolds. Results show that the bioreactor and static culture control groups displayed similar cell numbers and metabolic activity. However, histologically, peripheral cell-encapsulation was observed in the static controls, whereas, improved migration and homogenous cell distribution was seen in the bioreactor groups. Osteogenic markers investigated displayed greater levels of expression in the bioreactor groups compared to static controls. They demonstrated that this flow perfusion bioreactor improved construct homogeneity by preventing peripheral encapsulation whilst also providing an enhanced osteogenic phenotype over static controls. ${ }^{92}$

Barthold and other researches, in 2005, ${ }^{93}$ constructed a perfusion chamber bioreactor (single chamber), to analyze and identify soluble factors, such as the formation of 1-lactate, lactate dehydrogenase, collagen I C-terminal propeptide, soluble ALP and OC during the culture of rabbit bone marrow MSCs to get detailed information about the differentiation of the osteogenic cells. ${ }^{93}$ This same bioreactor was used to test human trabecular bone cells seeded onto three different types of scaffolds (porous $\mathrm{CaCO} 3$, mineralized collagen, porous TCP), with $5 \mathrm{~mm}$ in diameter and $3 \mathrm{~mm}$ 
thick, were used, stacking nine samples that were simultaneously cultured in the bioreactor. The scaffolds were subsequently implanted in rat mandibules for 6 weeks. Scaffolds without cells and scaffolds cultured in static conditions were used as controls. Histomorphometric evaluation showed that neither seeding human trabecular bone cells nor the culturing technique increased the amount of early bone formation compared with the level provided by osteoconductive bone ingrowth from the defect edges. ${ }^{94}$

To engineer anatomically correct pieces, Grayson and his researcher's ${ }^{46}$ report showed that clinically sized, anatomically shaped, viable human bone grafts can be developed using hMSCs and a "biomimetic" scaffold-bioreactor system. They selected the temporomandibular joint (TMJ) condylar bone as their tissue model. Scaffolds were generated from fully decellularized trabecular bone by using digitized clinical images, seeded with hMSCs, and cultured with interstitial flow of culture medium. A bioreactor with a single chamber in the exact shape of a human TMJ was designed for controllable perfusion throughout the engineered construct. After 5 weeks of culture, tissue growth was evidenced by the formation of confluent layers of lamellar bone, a markedly increased volume of mineralized matrix, and the formation of osteoids. ${ }^{46}$ Yeatts et al. ${ }^{95}$ developed a bioreactor- the TPS - consisting of a tubular growth chamber and medium reservoir connected via a tubing circuit. The medium's flow is driven by a Multichannel peristaltic pump at $3 \mathrm{~mL} / \mathrm{min}$ for short-term studies and at either 3 or $10 \mathrm{~mL} /$ min for the long-term studies. The circuit consists of silicone tubing that is connected using silver ion-lined microbial resistant tubing connector. The growth chamber consists of length silicone tubing. The growth chamber has $13 \mathrm{~cm}$ in length and is packed with 30 cell seeded alginate beads. The tubing is placed in a cell culture $\mathrm{CO}_{2}$ incubator atmosphere. hMSCs were encapsulated in alginate beads (a total of 30 samples of $4 \mathrm{~mm}$ diameter per bioreactor) and medium was perfused through the growth chamber and around the tightly packed scaffolds enhancing nutrient transfer, while exposing the cells to shear stress. Results demonstrate that bioreactor culture supports early osteoblastic differentiation of hMSCs as shown by ALP gene expression and increases in the gene expression levels of OC, OP, and bone morphogenetic protein (BMP)-2. ${ }^{95}$

Bertrand et al., in 2011, ${ }^{96}$ build a single chamber perfusion bioreactor based on fluidized bed bioreactor concepts for culture of clinical size scaffolds. It consists of a vertical cylindrical polycarbonate chamber connected to a reservoir containing the culture medium in a closed loop arrangement. The connections between the bioreactor chamber and the reservoir and between the bioreactor and a peristaltic roller pump are made of silicone tubing, Multiple perfusion bioreactors, such as this were operated during experiments, using 140 units of coral scaffolds (each $3 \times 3 \times 3 \mathrm{~mm}^{3}$ ) for each bioreactor, and seeded with GFP-C3H10T1/2 cells. To establish the flow influence, an in vitro study was conducted with various flow rates. To investigate the osteogenic potential of bone constructs, an in vivo study was carried out using sheep MSCs, which were then subcutaneously implanted. The best flow rate determined for this bioreactor and this scaffold was the $10 \mathrm{~mL} / \mathrm{min}$ and 8 weeks as following the subcutaneous implantation in sheep, all retrieved samples had areas of mineralized bone and osteoid, with osteocytes located inside the matrix and a film of osteoblasts coating the newly deposited bone. ${ }^{96}$

Gardel et al., in 2013, ${ }^{97}$ developed a single chamber Bidirectional Continuous Perfusion Bioreactor (BCPB). The $\mathrm{BCPB}$ is composed by one vacuum and one peristaltic pump, connected through of a circular flow system, which are connected via gas-permeable, silicone tubing and tubing connectors, and also for rotational engines located in specific places, aiming at creating shears stresses, due to the medium flow perfusion using different gradients of pressure, to induce mechanical stimulations to the cells seeded onto the scaffolds. The passage of the flow from the interior to the exterior of the $3 \mathrm{D}$ support or from the exterior to the interior of the 3D support is carried out through the use of a rigid tube (polycarbonate) with perforations in its central part and that has the same length of the 3D support (that can have variable dimensions). This tube, containing the scaffold, is connected to a circular system and is located coaxially inside of the culture chamber. This culture chamber has four exits/ entrances and is tightly closed, by that same circular system, which allows the control of the flow and the gradient of pressure inside of the chamber and inside of the perforated tube. Therefore, this system enables to control the perfusion rate and gradient of flow, in the interior of the cell-scaffold constructs in culture, and it allow to culture constructs of significant dimensions, as it enable the access of nutrients to the interior of the material and the removal of the metabolic products from the interior of this, enabling the maintenance of the cells the viability. To prove the feasibility of this perfusion system, preliminary in vitro studies using SPCL fibbers mesh scaffolds (with $16 \mathrm{~mm}$ in diameter and $3 \mathrm{~mm}$ thickness with a concentric hole of $6 \mathrm{~mm}$ ), were seeded with goat marrow stromal cells with and stacked, completing a $42 \mathrm{~mm}$ thick construct. The samples were cultured for a period of 14 and 21 days of culture in the bioreactor at a flow rate of $1 \mathrm{~mL} / \mathrm{min}$, using static cultured constructs as controls. The results showed higher ALP activity levels in dynamic cultures (14 days of culture) than those obtained under static conditions. SEM and histological images showed cells occupying the interior of the scaffolds cultured in the bioreactor, while cells were predominantly on the surface of the GBMCSPCL constructs in the static cultures. ${ }^{97}$

In summary, the systems currently available for the culture of large sized constructs, described in this review, differ considerably with respect to ease of use, cost-effectiveness, and degree of additional osteogenic stimuli provided, as well as monitoring and manipulation options. Further optimization of these systems may be achieved by adapting specific stimuli and by combining biophysical and biochemical stimuli within one system. However, a major challenge will be the translation of such bioreactor-based concepts into clinically applicable designs, because this requires adapting current designs or developing new bioreactors that enable culturing constructs of large dimension for clinical use, in accordance with Good Manufacturing Practices.

\section{Large Animal Models}

\section{Selection of appropriate animal models}

Desirable attributes of an animal model include demonstration of similarities with humans, both in terms of physiological and pathological considerations, as well as being 
able to observe numerous subjects over a relatively short time frame. ${ }^{98,99}$ When deciding on the species of animal for a particular model there are several factors that should be considered, namely cost to acquire and care for animals, availability, acceptability to society, tolerance to captivity, and ease of housing. The welfare and housing of animals is usually covered by a Federal Animal Protection Act and may vary slightly between countries. The Animal Protection acts outline the minimum requirements in terms of housing dimensions, lighting, flooring etc. and must be complied with when undertaking an animal study. Other factors include low maintenance care, ease of handling, resistance to infection and disease, inter-animal uniformity, tolerance to surgery, adequate facilities, support staff, and an existing database of biological information for the species, ease of adaptability to experimental manipulation, ecological consequences and ethical implications. ${ }^{22,100}$ More specifically, for studies investigating bone-implant interactions, an understanding of the species specific bone characteristics-such as bone microstructure and composition, as well as bone modeling and remodeling properties, are important when later extrapolating the results to the human situation. Finally the size of the animal must be considered to ensure that it is appropriate for the number and size of implants chosen. ${ }^{22}$

Within a field of study, no single animal model will be appropriate for all purposes, nor can a model be dismissed as inappropriate for all purposes. Furthermore, multiple model systems are likely required to establish a broad body of knowledge. ${ }^{101}$ International standards established regarding the species suitable for testing implantation of materials in bone, state that dog, sheep, goat, pig are suitable large animal models. At least two of each of the species mentioned above should be used for assessing each treatment at each implantation period. ${ }^{22}$

\section{Animal models in bone repair research}

Animal models in bone repair research include representations of normal fracture healing, segmental bone defects, and fracture nonunions in which regular healing processes are compromised with the presence of a critical-sized defect site. ${ }^{102}$ In critical-sized segmental defect, models bridging of the respective defect does not occur despite a sufficient biological microenvironment, due to the removal of critical amounts of bone substance. In contrast, in a true nonunion deficient signaling mechanism, biomechanical stimuli or cellular responses may prevent defect healing rather than the defect size. ${ }^{103}$ Bone composition and biology of dog, sheep, goat, and pig are very similar to those of humans. Reviews of the literature comparing bone structure, composition, and biology in these animals identify modest differences in cancellous and cortical bone density at various sites, magnitude of sexual dimorphism, the age at which peak bone mass is achieved, and the rate and extent to which haversian remodeling replaces plexiform lamellar bone in the cortex of long bone. ${ }^{104}$ However, these points of variation do not provide evidence that any one of these animals provides a better match for human bone biology than the other. ${ }^{105}$ In a variety of study designs, pigs are considered the animal of choice and were described as a highly representative model of human bone regeneration processes in respect to anatomical and morphological features, healing capacity and remodeling, bone mineral density and concentration. ${ }^{106,107}$ Pigs tend to be least used, ${ }^{108}$ likely due to difficult temperament, anatomically short and thick long bones, and large size. The short bones do not allow for large gap defects because adequate fixation is difficult to achieve, ${ }^{105}$ which leads to the need for special implants, as one cannot use implants designed for human use. ${ }^{103}$ Nonhuman Primates (NHPs) are sometimes held up as the model of choice for prediction of clinical performance for bone repair and regeneration methods. This supposition is based on arguments of evolutionary proximity and similar structural anatomic, endocrine, digestive, and dietary features and immunology. Of the three common NHP species, only the baboon approaches the skeletal size range that humans share with large canines, sheep, and goats. NHPs are very expensive and present husbandry challenges that preclude models involving intensive wound assessment, management, or immobilization. Although NHPs do not have companion animal status, arguments of perceived evolutionary affiliation raise social and ethic questions related to increasing their use in research. ${ }^{105}$ Dogs are used most due to a rich background of prior experience, ease of husbandry, and accessibility. A large literature characterizing canine models supports continued preferential use of dogs in many settings, particularly in bone marrow biology and transplantation immunology. ${ }^{109-115}$ The use of dogs is being challenged, however, by social concerns regarding the dog as a companion animal. ${ }^{105}$ Although, the use of dogs as experimental models has significantly decreased mainly due to ethical issues, between 1998 and 2008 $\sim 9 \%$ of articles published in leading orthopedic and musculoskeletal journals described dogs as animal models for fracture healing research. ${ }^{108}$ Mature sheep and goats possess a body weight comparable to adult humans and long bone dimensions enabling the use of human implants. ${ }^{116}$ Sheep are readily available and docile, but can be frail and less resilient, particularly when not in a group. Goats are similar in size and skeletal anatomy to sheep; they have a thinner coat and less muscular bulk, and are more tolerant of stress and isolation. ${ }^{105}$ The mechanical loading environment occurring is well understood. ${ }^{117,118}$ Since no major differences in mineral composition ${ }^{119}$ are evident and both metabolic and bone remodeling rates are akin to humans, ${ }^{120}$ sheep and goats are considered a valuable models for human bone turnover and remodeling activity, ${ }^{103,121}$ making them an increasingly viable alternative for bone research. ${ }^{105}$

\section{Ovine models}

Ovines are a convenient large animal model for biomedical research because of ease of handling and housing, animal cost and acceptance to society as a research animal. ${ }^{122}$ Sheep are long boned, and allow the use of many systems of internal fixation. Sheep are readily available and docile, but can be frail and less resilient, particularly when not in a group. ${ }^{105}$ They are a less expensive animal model versus other species, and their size is conducive to the insertion of prosthetic implants comparable to those implanted in humans. The age of the animals, the timing of the study, and the duration of the experiment have to be considered in sheep versus other species. The use of a few widely accepted standardized sheep breeds would make interlaboratory comparisons easier, and disclosure of reproductive and 
dietary histories could further aid our understanding of the efficacy of this animal model. ${ }^{104}$ The number of sheep used in orthopedic research is increasing in the last decade involving fractures, osteoporosis, bone-lengthening and osteoarthritis, in comparison with companion animals. ${ }^{123}$ This increase in usage may be related to the ethical issues and negative public perception of using companion animals for medical research.22 Adult sheep offer the advantage of having a more similar body weight to humans and having long bones of dimensions suitable for the implantation of human implants and prostheses. ${ }^{116}$ Sheep are described as having a predominantly primary bone structure in comparison with the largely secondary bone of humans. Age-related changes in bone structure are also described; adult sheep have a plexiform bone structure comprising a combination of woven and lamellar bone within which vascular plexuses are sandwiched. Secondary, Haversian (osteonal) remodelling in sheep is more prevalent in old sheep. Aging results in secondary haversian remodeling that becomes more extensive at specific locations, such as the posterior aspect of long bones and in ribs. ${ }^{104}$ Haversian canal distribution has been shown to be less dense in ovine bone than in human bone ${ }^{124}$ and has been described as not uniformly distributed. ${ }^{22}$ Differences in bone density exist between the human and sheep, whereby sheep bone shows a significantly higher density and subsequently greater strength. Bone location must be considered when contemplating differences between human and sheep bones. In terms of mineral composition, humans and animals do not show significant differences. ${ }^{22}$ Despite the differences in bone structure being recognized, studies show that sheep are a valuable model for human bone turnover and remodeling activity. ${ }^{121}$ As found in other species, it is likely that bone location may also alter bone composition and turnover in the sheep. ${ }^{22}$

\section{Caprine models}

As previously mentioned, goats are similar in size and skeletal anatomy to sheep but have a thinner coat and less muscular bulk, and are more tolerant to stress and isolation. ${ }^{105}$ Goats are generally classified as gentle, inquisitive, placid, and easy to handle, as well as clean and hardy in nature, ${ }^{104}$ making them an increasingly viable alternative for bone research. ${ }^{105}$ Like sheep, goats are considered food producing animals and thus, also have the advantage of less critical public perception when used for research, than companion animals. When compared to other species, sheep and goats are reported to be more tolerant to environmental conditions. ${ }^{125}$ Histologically, the tibial cortical bone of goats does not have homogeneously distributed Haversian systems (concentrically oriented lamellar bone containing a centrally located blood vessel, also known as osteons). Similar to the sheep, where the haversian systems are nonuniformly distributed throughout individual bones, in the goat, the Haversian systems are located primarily in the cranial, cranio-lateral and medial sectors of the tibial diaphysis, while the caudal sector is mainly comprised of lamellar bone (where the collagen fibers are arranged in sheets and do not contain a central blood vessel). ${ }^{126}$ Liebschner, in $2004^{98}$ showed that, while there are small differences in the apparent and ash density between the goat and humans, these differences are probably not as significant as the differences found between anatomic sites of the same species. ${ }^{98}$ The mineral composition of bone does not vary significantly across species and therefore, one could conclude that this also holds true for the goat. ${ }^{22}$ Goat has a metabolic rate and bone remodeling rate similar to that of human's presenting a suitable animal model for testing human implants and materials as they are considered. ${ }^{120,127}$ However, the rate at which a bone graft is revascularised and converted into a vital trabecular structure is found to be faster in the goat, occurring at $\sim 3$ months in comparison to 8 months in humans. There is little information comparing the utility of goats versus sheep for implant-related studies. Therefore, the choice of which small ruminant to use most likely depends on availability and other factors. ${ }^{22}$

\section{Cell culture approach}

The possibility of isolating and expanding MSCs from a small sample of bone marrow and directing them to the osteogenic phenotype has been demonstrated for both animals (goats and sheep). Autologous approaches have also been considered in previous studies demonstrating that both ovine and caprine bone marrow MSCs have high viability and proliferation rates when fresh or after being cryopreserved, ${ }^{97,128-132}$ avoiding immune complex problems that interfere with the regenerative process, as well as with the patient follow-up. However, further studies should provide better understanding of the importance of the differentiation stage, as well as the time needed for osteogenic supplementation, to induce significant changes in bone formation in vivo. ${ }^{133}$ Furthermore, future studies should also focus on the standardization of animals used, considering different races, different ages (young, adult, and old), because it is well known that cells from different animals exhibit high variability in terms of proliferation and differentiation patterns.

\section{Critical/Cylindrical Size Defects}

Critical-sized defects are defined as "the smallest sized intraosseous wound in a particular bone and animal species that will not heal spontaneously during the "lifetime of the animal"103,134-136 $^{\prime 13}$ as a defect, which shows less than 10 percent bony regeneration during the lifetime of the animal. ${ }^{103,137}$ However, this has been redefined as segmental bone deficiencies of a length exceeding 2-2.5 times the diameter of the affected bone. ${ }^{103,138,139}$ Furthermore, critical defect size should also be defined in relation to the evaluation period of the study. For example, Pearce et al. 2007, ${ }^{22}$ refer that long term implantation periods for these species are given as $12,26,52$, and 78 weeks. ${ }^{22}$ Previous studies are described in the literature using different implantation periods in large animal models. For example, Berner et al, ${ }^{140}$ reported good results in terms of new bone formation upon implantation of cell-scaffold constructs for 6 and 12 weeks, while Rentsch et al. ${ }^{141}$ reported the same type of results upon 12 to 48 weeks of implantation, but the methodology used to develop both studies was different. ${ }^{140,141}$

A critical defect in long bones, however, can hardly be defined by size only. The phenomenon of regeneration is also influenced by species, anatomic location, associated periosteum and soft tissue, and biomechanical conditions, as well as age, metabolic and systemic influences, and related injuries affecting defect healing. ${ }^{103,134,138}$ 
Congenital abnormalities, cancer resections, nonunions or traumatic incidents are very common both in human and in veterinary traumatology, and as suggested above, these problems do not heal or regenerate spontaneously. In fact, the currently available therapies that are usually used in such clinical scenarios, mostly consisting on the use of auto or allografts, present several disadvantages. Tissue engineering, using scaffolds and stem cells offer the potential to overcome such limitations. Therefore, it is important that studies on scaffolds development for such applications envision the need for obtaining constructs with a cylindrical shape, as long bones show anatomically a cylindrical shape, and thus, facilitating the translation to clinical settings. The composition of the defect generally includes periosteum, cortical bone, and endosteum. After suture, the opening of the defect is bounded by overlying muscle or fat. The base of the defect may be cancellous bone and marrow, cortical bone, or muscle/fat, depending on defect length and orientation within the long bone. In general, defects in the metaphysis of young large animals will be comprised of highly vascular hematopoietic marrow. However, marrow in defects in the diaphysis will generally be fatty or yellow marrow, which is still vascular, but far less cellular. Advancing age in animals will also increase the ratio of fatty to hematopoietic marrow, changing the biological environment of the graft site. Soft tissue encroachment does not compromise bone formation in most cylindrical defects. Regardless, cylindrical critical defects can be very sensitive to detecting differences in efficacy between osteoconductive scaffold materials, as well as the effects of bioactive factors and cell transplantation. The uniform radial geometry of cylindrical defects also provides the potential for control and modeling of biological gradients relevant to bone regeneration. Due to the pattern of diffusion and vascular ingrowth that must be oriented from the periphery to the center of the defect, cylindrical defects are particularly well suited for time-oriented studies of mass transport (e.g., the influence of diffusion, cellular metabolic demand, local oxygen delivery or generation, or gradients in the delivery of bioactive factors), degradation rate of implants, cell transplantation (survival and migration) and variables modulating the rate of bone or tissue ingrowth or vascular invasion into an implant. ${ }^{105}$

\section{Creation of the Cylindrical Critical Size Defects in Large Animals}

Osteotomy approach techniques are used for the creation of cylindrical critical size defects and can be performed by using a $\mathrm{CO}_{2}$ Laser, ${ }^{142,143}$ Oscillating saw, ${ }^{138,144-152}$ Gigli saw, ${ }^{153,154}$ treaded saw ${ }^{155}$ and a chisel/osteotome. ${ }^{156-158}$ The edges of the defect are usually cut straight with less trauma but there are advantages and disadvantages in the choice of each technique. The $\mathrm{CO}_{2}$ laser produces a cut with little trauma, it's the most accurate to perform the osteotomy but quite expensive. Kuttenber et al.,143 demonstrated that bone healing is similar and undelayed after both laser and oscillating saw. For practical applications, precise control of the depth of laser cutting and easier manipulation of the osteotome are required. ${ }^{143}$ The oscillating saw makes a straight cut without causing trauma to surrounding soft tissue and bone thermal necrosis caused by cutting blade unit can be avoided by a continuous irrigation of saline solution at the time of the cut; the technique of holding the cutting is easy and fast and cheaper when compared with the $\mathrm{CO}_{2}$, but more expensive when compared with the manual saws. Manual saws are much cheaper than all others, but require physical strength to make the cut and the start of this may not be accurate due to the difficulty of supporting the saw on the rounded and smooth bone surface, and care must be taken not to cause damage to surrounding soft tissues. The chisel (osteotomes) techniques require a hammer to be performed, and is not the best choice to perform an osteotomy in a long bone as it may cause jagged cuts in the bone surface.

\section{Fixation of the Cylindrical Critical Size Defects in Large Animals}

To simulate human in vivo conditions as closely as possible, a variety of large cylindrical critical size defect models, mainly in sheep and goat, have been developed in the last decade to investigate the influence of different types of bone grafts on bone repair and regeneration. The method of fixation is an important variable to be studied in large cylindrical critical size defect models. Fixation should not only reflect what occurs in the clinic but also provide sufficient rigidity to support bone healing. ${ }^{159}$ The method of fixation is more important for defects within weight-bearing bones than the nonweight-bearing bones. ${ }^{160}$ At present, most long bone defect models use bone plates, interlocking intramedullary nails, and external fixator to fix the defect; thus, reflecting the situation within the clinic. ${ }^{159}$

Sufficient reduction and stability can be achieved by bone plates even in complicated fractures. ${ }^{161}$ Bone plate osteosynthesis is performed using standard instrumentation, differing according to the size of the implant and the type of plate fixation. Most studies on bone tissue engineering using caprine and ovine models are performed in the diaphyseal bone (tibia, femur) requiring the use of cortical screws that are a very efficient devices for fixing a splinting device, such as a plate. The goal is to achieve as much contact area as possible in a sufficiently stable implant of minimal size; it is recommended that the screw diameter should not exceed $40 \%$ of the diameter of the bone. There are a number of different sizes of cortex screws available to enable fixation of bones of different diameters. Newly developed screws for use in humans, such as self-tapping screws, monocortical screws and those used in locking systems, are likely to find an increasing application in animal models. Various types of bone plates are available in the market for use as bone fixation methods, such as dynamic compression plates (DCP), limited contact DCP (LC-DCP), locking compression plates (LCP), non DCP and reconstruction plates. For sheep and goat weighing between 15 and $45 \mathrm{~kg}$, plates with screws of 3.5 and $4.5 \mathrm{~mm}$ are used, but for weights superior of these values the use of screws $5.5 \mathrm{~mm}$ should be considered. However, conventional bone plates can result in histologically and radiologically verifiable bone loss, which has been attributed to stress protection (Wolff's law). An increase in cortical bone porosity proximate to the plate soon after bone plate osteosynthesis has been observed. This porosity is explained by impaired vascular perfusion underneath the plate due to high compression forces between plate, periosteum, and bone. ${ }^{103,162}$ New plate systems were developed where load and torque transmission act through the screws 
(interlocking screws), the stabilization system acts like an external skeletal fixator (ESF) making a total plate-bone contact unnecessary to achieve stable fixation. ${ }^{103}$ The plates can be placed in three different functions: compression mode (the plate creates an axial compression), neutralization mode (the plate protects the interfragmentary compression), biological mode (the plate acts as a splint to maintain the correct length of the bone and the normal spatial alignment of the joints proximal and distal to the fracture).

For example, to study the effects of different bioceramics during bone repair of a tibial defect model in sheep of $16 \mathrm{~mm}$ length, Gao et al., ${ }^{163}$ implanted biocoral and TCP cylinders. The defects were stabilized medially using two overlapping contoured autocompression plates of $4 \mathrm{~mm}$ thickness (eight and six holes) and cortical screws. ${ }^{163}$ However, this method of fixation is not commonly used in the clinical practice. A DCP stainless steel plate was used by Kirker-Head et al., ${ }^{164}$ for the stabilization of a $25 \mathrm{~mm}$ long mid-diaphyseal critical size defect in long bone of the sheep, to observe the use of recombinant human BMP-2 and a poly [D, L-(lactide-coglycolide)] in 1 year of the long-term healing. ${ }^{164}$ Several studies selected this as a method of fixation bone plate for osteosynthesis. Wefer et al., ${ }^{165}$ used as a method of fixing an anterolateral plate to implant a porous hydroxyapatite scaffold in a $20 \mathrm{~mm}$ critical size defect in the sheep long bone, to develop and test a scoring system based on real-time ultrasonography. ${ }^{165}$ Meinel et al., ${ }^{148}$ performed a noncritical $10 \mathrm{~mm}$ segmental tibia defect using for stabilization a $3.5 \mathrm{~mm}$ of 11 hole DCP plate, to study the treatment of bone defects by releasing of the insulin-like growth factor(IGF-1) from biodegradable poly(lactide-co-glycolide) microspheres. ${ }^{166}$ To evaluate a synthetic calcium phosphate multiphase biomaterial, Mastrogiacomo et al., ${ }^{167}$ created a $48 \mathrm{~mm}$ tibial defect model in sheep and stabilized with a $4.5 \mathrm{~mm}$ neutralizing plate. ${ }^{167}$ However, Reichert et al., ${ }^{103}$ in their review article reported that they observed bent plates and axial deviations in presented X-ray and CT images, and concluded that the chosen fixation, performed by Mastrogiacomo et al., seemed insufficient in this study. ${ }^{103}$ Teixeira et al., ${ }^{168}$ created a tibial critical size defects of $35 \mathrm{~mm}$ size, being the bone defects in the diaphysis of the sheep stabilized with a titanium bone plate (103 $\mathrm{mm}$ in length, $2 \mathrm{~mm}$ thickness, and $10 \mathrm{~mm}$ width), but as reported by the authors, plate bending occurred in $42 \%$ of the animals most likely caused by insufficient thickness of the fixation device. ${ }^{168}$ To demonstrate that the compartmentalization of tissues may have an important role in bone regeneration in long-bone defects, Klaue et al., ${ }^{169}$ created a foreign-body membrane with a temporary polymethylmethacrylate spacer with the same critical size of the defect created $(30 \mathrm{~mm})$ on mid-diaphyseal of the sheep femurs and stabilized with an eight-hole, $4.5 \mathrm{~mm}$ low covering dynamic-compression plate (LC-DCP). The obtained results suggested that regeneration of bone can be enhanced by compartmentalisation of the bone defect. ${ }^{169}$ To study the different immunological characteristics between Human and ovine MSCs, Niemeyer et al., ${ }^{150}$ applied a xenogenic transplant (human MSCs) and an autologous transplant (ovine MSCs) to a sheep animal model. For this purpose, they performed a critical size defect of $30 \mathrm{~mm}$ on the tibial diaphysis and stabilized it with a seven-hole LCP and selftaping screw. The results demonstrated that the xenogenic transplantation of human MSCs led to poorer bone regen- eration than the autologous transplantation of ovine MSCs. Nevertheless, no local or systemic rejection reactions could be observed after xenogenic transplantation of human MSCs. ${ }^{150}$ To investigate whether MSCs and osteogenic protein-1 (OP-1) can improve allograft integration, Bella et al., ${ }^{170}$ performed a $30 \mathrm{~mm}$ full-size bone defect in the mid-diaphysis of the metatarsal bone of a sheep and stabilized with a sevenhole titanium DCP ( $3.5 \mathrm{~mm}$ wide, $10.5 \mathrm{~mm}$ long). The results demonstrated that the association of MSCs and OP-1 improve bone allograft integration promoting an almost complete bone restoring when compared to other groups: allograft alone (control group), MSC group, OP-1 group. ${ }^{170}$

A locked intramedullary nail is a stainless steel nail in which our titanium nail is placed within the medullary cavity and is locked to the bone by screws or bolts crosses the bone and passes through the holes in the nail. They are available in several diameters and can be locked with screws or bolts of 4.5 or $3.5 \mathrm{~mm}$ diameter and are the most suitable for use in ovine and caprine models. Locked intramedullary nails resist bending, axial, and rotational forces because they are locked with either bone screws or locking bolts. These are most effectively used to stabilize mid-diaphyseal fractures of the femur and tibia in animal models used in tissue engineering approaches and in the last decade several researchers have used this method for orthopedic fixation in their studies. To establish a new critical bone defect model of $30 \mathrm{~mm}$, den Boer et al., ${ }^{121}$ used an interlocking intramedullary nail $\left(\mathrm{AO}^{\circledR}\right.$ unreamed humeral nail); the defect (30 mm length) was inflicted on sheep tibiae and bone healing was quantified through X-ray absorptiometry. ${ }^{121}$ A study conducted by Bloemers et al., ${ }^{171}$ indicated that new calcium phosphate based materials might be a potential alternative for autologous bone grafts. To conduct this study, they used a segmental tibial defect $(30 \mathrm{~mm})$ in sheep fixed by an $\mathrm{AO}$ unreamed interlocking titanium tibial nail. ${ }^{171}$ To see the effect of platelet rich plasma on new bone formation in a $25 \mathrm{~mm}$ diaphyseal tibial defect in sheep, Sarkar et al. ${ }^{172}$ stabilized the defect with intramedullary nail with locking screws on the proximal and distal surface and added stainless steel plate applied medially ${ }^{172}$ The effect of chondroitine sulphate on bone remodeling and regeneration was investigated by Schneiders et al., ${ }^{173}$ for which they performed a $30 \mathrm{~mm}$ tibial mid-diaphyseal defect site and reconstructed it using hydroxyapatite/collagen cement cylinders. The stabilization was achieved by insertion of a universal tibial nail (UTN, Synthes ${ }^{\circledR}$; Bochum). ${ }^{173}$ To investigate the feasibility of BMSCs on coral scaffold infected with adenoviral vector containing the BMP-7 gene (AdBMP7), Zhu et al., ${ }^{152}$ performed a segmental bone defect of the $25 \mathrm{~mm}$ in length at the mid-portion of the femoral diaphysis of the goat, and stabilized this defect with an internal fixation rod and interlocking nails. ${ }^{152}$

The interlocking intramedullary nail can be applied in two different ways, either static or dynamic compression. depending on the number of screws to use and their positioning(distal or proximal), the outcome of animal experiments and clinical retrievals strongly suggested that, particularly the mechanical load, has a positive effect on bone graft incorporation. ${ }^{174-176}$ To prove this, Bullens et al., ${ }^{151}$ studied if a static or dynamic mode of nail fixation influenced the healing of segmental defect reconstructions in long bones. In this study, $35 \mathrm{~mm}$ critical size defects in goat femurs were 
reconstructed using a cage filled with firmly impacted morsellised allograft mixed with a hydroxyapatite paste $\left(\right.$ Ostim $\left.{ }^{\circledR}\right)$. All reconstructions were stabilized with an interlocking intramedullary stainless steel unreamed femur nail and $\mathrm{AO}$ locking screws. Authors found that healing of these defects was not significantly influenced by the mode of fixation of the nail in this animal model. ${ }^{151}$ To analyze the efficacy of allogeneic mesenchymal precursor cells in the repair of sheep tibial segmental defects, Field et al. ${ }^{177}$ created $30 \mathrm{~mm}$ defects and stabilized them with a locking intramedullary nail and allowed to heal over a 9-month-period. The group treated with allogeneic cells and scaffolds displayed a significantly greater level of callus formation and rate of bone apposition in the defect, compared to the scaffolds without cells. ${ }^{177}$

ESF and circular external fixation (Ilizarov model) are two types of the bone fixation, which have been more widely used in large animal studies, offering versatility and smooth application. In fact, They offers major advantages over "conventional methods" in the management of fractures caused by the creation of critical-size defects, as the fact that they are relatively easy to apply, maintaining limb use and joint mobility, are well tolerated by patients, have a low cost when compared to plate systems, and involve a relatively low risk procedure. In addition, external fixators are associated to minimal intra-operative trauma and the surrounding soft tissues are only marginally affected. The linear external fixators are composed of bars and clamps that can vary in amount depending on the type to be applied (type I frame, type II frame, and type III frame), being the type III frame the most strong of all. The distal and proximal bone fragments should be secured with at least two pins at each end, and the conformation of these pins can be, smooth pin, negative and positive threaded pins. One of the most common complications with linear external fixators is the pin loosening often resulting in pin track infections, but this complication can be eliminated with the use of positive threaded pins. The linear external fixation has been selected by some research groups as a method of bone fixation to be implemented. For example, to study the effect of bioresorbable polylactide membranes, applied alone and/or in combination with autologous bone graft, in bone healing, Gugala et al. ${ }^{178}$ performed a critical defect of $40 \mathrm{~mm}$ in sheep tibia and stabilized with an $\mathrm{AO}$ external fixator type II frame. Only in groups where the defect was filled with autogenous cancellous bone graft and covered with a membrane, defect healing was observed. ${ }^{178}$ Maissen et al. ${ }^{179}$ studied the influence of rhTGFbeta-3 loaded on a poly (L/DL-lactide) carrier, as compared to the carrier only, autologous cancellous bone graft, and to untreated defects, on mechanical and radiological parameters of a healing bone defect in the sheep tibia. An $18 \mathrm{~mm}$ long defect was fixed with a unilateral (type I frame) external fixator and the results showed significant differences between the groups, indicating the autologous cancellous bone graft bone graft treatment performed better than the others group. ${ }^{179}$

Based on its design and configuration, circular fixators are indicated for the treatment for lengthening or shortening bone, limb deformities, arthrodesis, nonunion and fractures by presenting greater rigidity and versatility, but few researchers choose this method for bone fixation in their studies in large animal models. Recently, Liu et al., ${ }^{180}$ re- ported on the use of highly porous b-TCP scaffolds to repair $26 \mathrm{~mm}$ long goat tibial defects, stabilized using a circular external fixator. Study groups included defects treated with b-TCP ceramic cylinder loaded with osteogenically induced autologous bone marrow stromal cells, beta-TCP ceramic cylinder without cells and defects left untreated. X-ray, $\mu \mathrm{CT}$ and histological analysis performed at 32 weeks postimplantation showed that the porous beta-TCP ceramic cylinder loaded with cells led to was significantly better results than all the other groups. ${ }^{180}$

\section{A 10 Year View from Now, on the Future of Bone Tissue Engineering}

Upon almost two decades of studies and developments in the field of TERM, many aspects related to this area are yet to be studied and/or developed. Drawbacks of of stem cell based therapies that have already been identified, such as: Heterogeneity of cell populations, genetic instability, high mutation rate during in vitro manipulations, and immune responses induced after stem cell transplantation, should be deeply studied and understood to achieve efficient solutions.

Concerning the in vitro culture of scaffolds-cells constructs, it is evident that bioreactors perfusion systems enable better results regarding the induction of osteogenic differentiation and de novo bone formation in vitro and in vivo, despite their more complex designs, as compared to static culturing systems. Nevertheless, many progresses can be made to facilitate and overspread the utilization of these systems in future. Studies should focus on determining optimal flow rates for each bioreactor/scaffolds/cell type combination and develop systems that can also be used for dynamic cell seeding, without prejudice of initial cell adhesion and proliferation. This could significantly reduce handling steps and enable more efficient bioreactors.

Large animal models (often referred to as "nonrodent species") provide important advantages for studies aimed at assessing the in vivo functionality of TE constructs, including the large size bones, similarity to human physiology, and pathology and longer life, thereby facilitating the translation of the studies outcomes for predicting the behavior in humans. However, animal model studies need to be improved to better predict the effectiveness of the treatment strategies in clinical trials. Several possible causes of the disparity between the results of animal studies and clinical trials have been identified, including failure to acknowledge the limitations of animal models, inadequate animal data and conclusions from them, less than optimal disease models and overestimation of treatment efficacy. These problems should be addressed in the design and execution of preclinical animal model studies involving bone stem-cell based therapies. New horizons are opened in TERM, whether clinicians, surgeons, scientists, and entrepreneurs begin to work in multidisciplinary teams. These progresses will aid in ensuring that TERM fulfills the expectations for revolutionizing medical care.

\section{Conclusions}

Bone TERM has the potential to become a real alternative to autologous bone grafts, but before this can happen it is necessary to solve the problem of homogenously supplying oxygen and nutrient to cells within a large scaffold. Several 
bioreactors have been developed that hold potential to improve mass transfer in large cellular scaffold constructs and to apply favorable mechanical stimuli; thus, facilitating the cellular viability, proliferation and differentiation. One of the major breakthroughs was the development of the perfusion bioreactor system that increase the mass transfer of cellular scaffolds not only at the periphery but also within the interior of scaffolds, increasing cellular proliferation, and osteogenic differentiation. A significant volume of work was reported in this review, related to the use of perfusion bioreactor systems for bone tissue engineering. However, most perfusion bioreactors described herein do not enable the culture of large constructs. Thus, additional efforts are required to develop improved design for the successful culture of large scaffolds to be used in clinical settings. Given the amount of research conducted on many bioreactor systems, the next obvious step should be the evaluation of constructs developed in perfusion bioreactors, using large animal models and critical size defects, to enable easier translation of outcomes to the clinical scenario. However, little work has been reported using perfusion bioreactor cultured bone tissue engineering constructs implanted in critical size defects animal models. Therefore, the selection of an experimental model, to access the feasibility of a determined tissue engineering concept, is critical to the success of the preclinical studies and must be considered in the light of the proposed ideas to be tested. The rapid progression of this research area and the great number of novel developments must be supported by systematic assessment based on clinical practicability and experience, the knowledge of basic biological principles, medical needs and commercial practicality. Preferentially, an animal model should match the clinical setting that it is to reflect, both in terms of creation of the defect and the cells or scaffolds that will be used for repairing it. It is clear that each of the species discussed here demonstrate unique advantages and disadvantages in terms of their appropriateness as a model for demonstrating the response of bone tissue to an implant material. Considerations should include the species and the type of defect (location, size, method of creation and repair, and fixation), as well as the post operation care and monitoring. Although there is no ideal animal model, a deep understanding of the differences of bone (macroscopic, microscopic and remodeling attributes) are likely to improve the choice of model and interpretation of these in vivo studies. Probably, a combination of different animal models for different strategies may be more realistic. However, to allow comparison between different studies is fundamental that animal models, methods of orthopedic fixation, surgical procedures and devices for measuring qualitatively, quantitatively and objectively the samples are standardized to achieve a reliable data pool as a base for future lines of research in TERM.

\section{Acknowledgments}

Leandro Gardel acknowledges the Portuguese Foundation for Science and Technology (FCT) for the PhD scholarship (ref SFRH/BD/66714/2009).

\section{Disclosure Statement}

None of the authors have any potential conflicts of interest to declare.

\section{References}

1. Young, R.G., Butler, D.L., Weber, W., Caplan, A.I., Gordon, S.L. and Fink, D.J. Use of mesenchymal stem cells in a collagen matrix for Achilles tendon repair. J Orthop Res 16, 406, 1998.

2. Awad, H.A., Butler, D.L., Boivin, G.P., Smith, F.N.L., Malaviya, P., Huibregtse, B. and Caplan, A.I. Autologous mesenchymal stem cell-mediated repair of tendon. Tissue Eng 5, 267, 1999.

3. Langer, R., and Vacanti, J.P. Tissue engineering. Science 260, 920, 1993.

4. Nerem, R.M., and Sambanis, A. Tissue engineering: from biology to biological substitutes. Tissue Eng 1, 3, 1995.

5. Wu, F., Dunkelman, N., Peterson, A., Davisson, T., De la Torre, R., and Jain, D. Bioreactor development for tissueengineered cartilage. Ann N Y Acad Sci 875, 405, 1999.

6. Griffith, L.G., and Naughton, G. Tissue engineeringCurrent challenges and expanding opportunities. Science 295, 1009, 2002.

7. Meyer, U., Szulczewski, D.H., Moller, K., Heide, H., Jones, D.B., Gross, U., Vanwachem, P.B., Bagamdisa, F.B., Dekker, A., and Davies, J.E. Attachment kinetics and differentiation of osteoblasts on different biomaterials. Cells Mater 3, 129, 1993.

8. Ratcliffe, A., and Niklason, L.E. Bioreactors and bioprocessing for tissue engineering. Ann N Y Acad Sci 961, 210, 2002.

9. Pei, M., Solchaga, L.A., Seidel, J., Zeng, L., Vunjak-Novakovic, G., Caplan, A.I., and Freed, L.E. Bioreactors mediate the effectiveness of tissue engineering scaffolds. Faseb J 16, 1691, 2002.

10. Williams, C., and Wick, T.M. Perfusion Bioreactor for small diameter tissue-engineered arteries. Tissue Eng 10, 930, 2004.

11. Korossis, S.A., Bolland, F., Kearney, J.N., Fisher, J., and Ingham, E. Bioreactors in tissue engineering. In: Ashammakhi, N., and Reis, R.L., eds. Topics in Tissue Engineering, Expertissues. 2005, p.1.

12. Freed, L.E., Marquis, J.C., Nohria, A., Emmanual, J., Mikos, A.G., and Langer, R. Neocartilage formation in vitro and in vivo using cells cultured on synthetic biodegradable polymers. J Biomed Mater Res 27, 11, 1993.

13. Freed, L.E., Marquis, J.C., Vunjaknovakovic, G., Emmanual, J., and Langer, R. Composition of cell-polymer cartilage implants. Biotechnol Bioeng 43, 605, 1994.

14. Vunjak-Novakovic, G., Freed, L.E., Biron, R.J., and Langer, R. Effects of mixing on the composition and morphology of tissue-engineered cartilage. J Am Inst Chem Eng 42, 850, 1996.

15. Wu, W., Feng, X., Mao, T.Q., Feng, X.H., Ouyang, H.W., Zhao, G.F., and Chen, F.L. Engineering of human tracheal tissue with collagen-enforced poly-lactic-glycolic acid nonwoven mesh: a preliminary study in nude mice. Br J Oral Maxillofac Surg 45, 272, 2007.

16. Schreiber, R.E., Dunkelman, N.S., Naughton, G., and Ratcliffe, A. A method for tissue engineering of cartilage by cell seeding on bioresorbable scaffolds. Ann N Y Acad sci 875, 398, 1999.

17. Grande, D.A., Halberstadt, C., Naughton, G., Schwartz, R., and Manji, R. Evaluation of matrix scaffolds for tissue engineering of articular cartilage grafts. J Biomed Mater Res 34, 211, 1997.

18. Chromiak, J.A., Shansky, J., Perrone, C., and Vandenburgh, H.H. Bioreactor perfusion system for the long-term main- 
tenance of tissue-engineered skeletal muscle organoids. In Vitro Cell Dev Biol Anim 34, 694, 1998.

19. Bancroft, G.N., Sikavitsas, V.I., and Mikos, A.G. Design of a flow perfusion bioreactor system for bone tissue-engineering applications. Tissue Eng 9, 549, 2003.

20. Goncalves, A., Costa, P., Rodrigues, M.T., Dias, I.R., Reis, R.L., and Gomes, M.E. Effect of flow perfusion conditions in the chondrogenic differentiation of bone marrow stromal cells cultured onto starch based biodegradable scaffolds. Acta Biomater 7, 1644, 2011.

21. Gomes, M.E., Holtorf, H.L., Reis, R.L., and Mikos, A.G. Influence of the porosity of starch-based fiber mesh scaffolds on the proliferation and osteogenic differentiation of bone marrow stromal cells cultured in a flow perfusion bioreactor. Tissue Eng 12, 801, 2006.

22. Pearce, A.I., Richards, R.G., Milz, S., Schneider, E., and Pearce, S.G. Animal models for implant biomaterial research in bone: a review. Euroean Cells Mater 13, 1, 2007.

23. Sikavitsas, V.I., Bancroft, G.N., and Mikos, A.G. Formation of three-dimensional cell/polymer constructs for bone tissue engineering in a spinner flask and a rotating wall vessel bioreactor. J Biomed Mater Res 62, 136, 2002.

24. Mygind, T., Stiehler, M., Baatrup, A., Li, H., Zoua, X., Flyvbjerg, A., Kassem, M., and Bunger, C. Mesenchymal stem cell ingrowth and differentiation on coralline hydroxyapatite scaffolds. Biomaterials 28, 1036, 2007.

25. Goldstein, A.S., Juarez, T.M., Helmke, C.D., Gustin, M.C., and Mikos, A.G. Effect of convection on osteoblastic cell growth and function in biodegradable polymer foam scaffolds. Biomaterials 22, 1279, 2001.

26. Wendt, D., Marsano, A., Jakob, M., Heberer, M., and Martin, I. Oscillating perfusion of cell suspensions through three-dimensional scaffolds enhances cell seeding efficiency and uniformity. Biotechnol Bioeng 84, 205, 2003.

27. Meinel, L., Karageorgiou, V., Fajardo, R., Snyder, B., Shinde-Patil, V., Zichner, L., Kaplan, D., Langer, R., and Vunjak-Novakovic, G. Bone tissue engineering using human mesenchymal stem cells: effects of scaffold material and medium flow. Ann Biomed Eng 32, 112, 2004.

28. Yeatts, A.B., and Fisher, J.P. Bone tissue engineering bioreactors: dynamic culture and the influence of shear stress. Bone 48, 171, 2011.

29. Depprich, R., Handschel, J., Wiesmann, H.P., Jasche-Meyer, J., and Meyer, U. Use of bioreactors in maxillofacial tissue engineering. Br J Oral Maxillofac Surg 46, 349, 2008.

30. Vandenburgh, H.H., Hatfaludy, S., Karlisch, P., and Shansky, J. Mechanically induced alterations in cultured skeletal-muscle growth. J Biomech 24, 91, 1991.

31. Buschmann, M.D., Gluzband, Y.A., Grodzinsky, A.J., and Hunziker, E.B. Mechanical compression modulates matrix biosynthesis in chondrocyte agarose culture. J Cell Sci 108, 1497, 1995.

32. Eschenhagen, T., Fink, C., Remmers, U., Scholz, H., Wattchow, J., Weil, J., Zimmerman, W., Dohmen, H.H., Schafer, H., Bishopric, N., Wakatsuki, T., and Elson, E.L. Three-dimensional reconstitution of embryonic cardiomyocytes in a collagen matrix: a new heart muscle model system. Faseb J 11, 683, 1997.

33. Carver, S.E., and Heath, C.A. Semi-continuous perfusion system for delivering intermittent physiological pressure to regenerating cartilage. Tissue Eng 5, 1, 1999.

34. Matthews, J.B., Mitchell, W., Stone, M.H., Fisher, J., and Ingham, E. A novel three-dimensional tissue equivalent model to study the combined effects of cyclic mechanical strain and wear particles on the osteolytic potential of primary human macrophages in vitro. Proc Inst Mech Eng Part H- J Eng Med 215, 479, 2001.

35. Du, D., Furukawa, K.S., and Ushida, T. 3D culture of osteoblast-like cells by unidirectional or oscillatory flow for bone tissue engineering. Biotechnol Bioeng 102, 1670, 2009.

36. Freed, L.E., and Vunjaknovakovic, G. Cultivation of cellpolymer tissue constructs in simulated microgravity. Biotechnol Bioeng 46, 306, 1995.

37. Vandenburgh, H., DelTatto, M., Shansky, J., Lemaire, J., Chang, A., Payumo, F., Lee, P., Goodyear, A., and Raven, L. Tissue-engineered skeletal muscle organoids for reversible gene therapy. Hum Gene Ther 7, 2195, 1996.

38. Kim, S.S., Utsunomiya, H., Koski, J.A., Wu, B.M., Cima, M.J., Sohn, J., Mukai, K., Griffith, L.G., and Vacanti, J.P. Survival and function of hepatocytes on a novel three-dimensional synthetic biodegradable polymer scaffold with an intrinsic network of channels. Ann Surg 228, 8, 1998.

39. Bilodeau, K., and Mantovani, D. Bioreactors for tissue engineering: focus on mechanical constraints. A comparative review. Tissue Eng 12, 2367, 2006.

40. Gomes, M.E., Sikavitsas, V.I., Behravesh, E., Reis, R.L., and Mikos, A.G. Effect of flow perfusion on the osteogenic differentiation of bone marrow stromal cells cultured on starch-based three-dimensional scaffolds. J Biomed Mater Res Part A 67A, 87, 2003.

41. Gomes, M.E., Bossano, C.M., Johnston, C.M., Reis, R.L., and Mikos, A.G. In vitro localization of bone growth factors in constructs of biodegradable scaffolds seeded with marrow stromal cells and cultured in a flow perfusion bioreactor. Tissue Eng 12, 177, 2006.

42. Zhao, F., Chella, R., and Ma, T. Effects of shear stress on 3$\mathrm{D}$ human mesenchymal stem cell construct development in a perfusion bioreactor system: experiments and hydrodynamic modeling. Biotechnol Bioeng 96, 584, 2007.

43. Sikavitsas, V.I., Bancroft, G.N., Lemoine, J.J., Liebschner, M.A.K., Dauner, M., and Mikos, A.G. Flow perfusion enhances the calcified matrix deposition of marrow stromal cells in biodegradable nonwoven fiber mesh scaffolds. Ann Biomed Eng 33, 63, 2005.

44. Grayson, W.L., Bhumiratana, S., Cannizzaro, C., Chao, P.H.G., Lennon, D.P., Caplan, A.I., and Vunjak-Novakovic, G. Effects of initial seeding density and fluid perfusion rate on formation of tissue-engineered bone. Tissue Eng Part A 14, 1809, 2008.

45. Li, D.Q., Tang, T.T., Lu, J.X., and Dai, K.R. Effects of flow shear stress and mass transport on the construction of a large-scale tissue-engineered bone in a perfusion bioreactor. Tissue Eng Part A 15, 2773, 2009.

46. Grayson, W.L., Frohlich, M., Yeager, K., Bhumiratana, S., Chan, M.E., Cannizzaro, C., Wan, L.Q., Liu, X.S., Guo, X.E., and Vunjak-Novakovic, G. Engineering anatomically shaped human bone grafts. Proc Natl Acad Sci U S A 107, 3299, 2010.

47. Yang, J.F., Cao, C., Wang, W., Tong, X.M., Shi, D.Y., Wu, F.B., Zheng, Q., Guo, C.J., Pan, Z.J., Gao, C.Y., and Wang, J.F. Proliferation and osteogenesis of immortalized bone marrow-derived mesenchymal stem cells in porous polylactic glycolic acid scaffolds under perfusion culture. J Biomed Mater Res Part A 92A, 817, 2010.

48. Frohlich, M., Grayson, W.L., Marolt, D., Gimble, J.M., Kregar-Velikonja, N., and Vunjak-Novakovic, G. Bone grafts engineered from human adipose-derived stem cells in perfusion bioreactor culture. Tissue Eng Part A 16, 179, 2010. 
49. Holtorf, H.L., Sheffield, T.L., Ambrose, C.G., Jansen, J.A., and Mikos, A.G. Flow perfusion culture of marrow stromal cells seeded on porous biphasic calcium phosphate ceramics. Ann Biomed Eng 33, 1238, 2005.

50. Hosseinkhani, H., Inatsugu, Y., Hiraoka, Y., Inoue, S., and Tabata, Y. Perfusion culture enhances osteogenic differentiation of rat mesenchymal stem cells in collagen sponge reinforced with poly(glycolic acid) fiber. Tissue Eng 11, 1476, 2005.

51. Janssen, F.W., Oostra, J., van Oorschot, A., and van Blitterswijk, C.A. A perfusion bioreactor system capable of producing clinically relevant volumes of tissue-engineered bone: in vivo bone formation showing proof of concept. Biomaterials 27, 315, 2006.

52. Yu, X.J., Botchwey, E.A., Levine, E.M., Pollack, S.R., and Laurencin, C.T. Bioreactor-based bone tissue engineering: the influence of dynamic flow on osteoblast phenotypic expression and matrix mineralization. Proc Natl Acad Sci U S A 101, 11203, 2004.

53. Zhao, F., and Ma, T. Perfusion bioreactor system for human mesenchymal stem cell tissue engineering: dynamic cell seeding and construct development. Biotechnol Bioeng 91, 482, 2005.

54. Sailon, A.M., Allori, A.C., Davidson, E.H., Reformat, D.D., Allen, R.J., and Warren, S.M. A novel flow-perfusion bioreactor supports $3 \mathrm{D}$ dynamic cell culture. J Biomed Biotechnol 2009, 873, 2009.

55. Porter, B., Zauel, R., Stockman, H., Guldberg, R., and Fyhrie, D. 3-D computational modeling of media flow through scaffolds in a perfusion bioreactor. I Biomech 38, 543, 2005.

56. Voronov, R., Gordon, S.V., Sikavitsas, V., and Papavassiliou, D.V. Computational modeling of flow-induced shear stresses within 3D salt-leached porous scaffolds imaged via micro-CT. J Biomech 43, 1279, 2010.

57. Voronov, R.S., VanGordon, S.B., Shambaugh, R.L., Papavassiliou, D.V., and Sikavitsas, V.I. 3D Tissue-engineered construct analysis via conventional high-resolution microcomputed tomography without $X$-ray contrast. Tissue Eng Part C 19, 1, 2012.

58. Rauh, J., Milan, F., Gunther, K.P., and Stiehler, M. Bioreactor systems for bone tissue engineering. Tissue Eng Part B Rev 17, 263, 2011.

59. Cartmell, S.H., Porter, B.D., Garcia, A.J., and Guldberg, R.E. Effects of medium perfusion rate on cell-seeded threedimensional bone constructs in vitro. Tissue Eng 9, 1197, 2003.

60. Botchwey, E.A., Pollack, S.R., El-Amin, S., Levine, E.M., Tuan, R.S., and Laurencin, C.T. Human osteoblast-like cells in three-dimensional culture with fluid flow. Biorheology 40, 299, 2003.

61. Wang, Y.C., Uemura, T., Dong, R., Kojima, H., Tanaka, J., and Tateishi, T. Application of perfusion culture system improves in vitro and in vivo osteogenesis of bone marrowderived osteoblastic cells in porous ceramic materials. Tissue Eng 9, 1205, 2003.

62. Batra, N.N., Li, Y.J., Yellowley, C.E., You, L.D., Malone, A.M., Kim, C.H., and Jacobs, C.R. Effects of short-term recovery periods on fluid-induced signaling in osteoblastic cells. J Biomech 38, 1909, 2005.

63. van den Dolder, J., Bancroft, G.N., Sikavitsas, V.I., Spauwen, P.H.M., Jansen, J.A., and Mikos, A.G. Flow perfusion culture of marrow stromal osteoblasts in titanium fiber mesh. J Biomed Mater Res Part A 64A, 235, 2003.
64. Vance, J., Galley, S., Liu, D.F., and Donahue, S.W. Mechanical stimulation of MC3T3 osteoblastic cells in a bone tissue-engineering bioreactor enhances prostaglandin E2 release. Tissue Eng 11, 1832, 2005.

65. Bancroft, G.N., Sikavitsas, V.I., van den Dolder, J., Sheffield, T.L., Ambrose, C.G., Jansen, J.A., and Mikos, A.G. Fluid flow increases mineralized matrix deposition in $3 \mathrm{D}$ perfusion culture of marrow stromal osteoblasts in a dosedependent manner. Proc Natl Acad Sci U S A 99, 12600, 2002.

66. Holtorf, H.L., Jansen, J.A., and Mikos, A.G. Flow perfusion culture induces the osteoblastic differentiation of marrow stromal cell-scaffold constructs in the absence of dexamethasone. J Biomed Mater Res Part A 72A, 326, 2005.

67. Alvarez-Barreto, J.F., Linehan, S.M., Shambaugh, R.L., and Sikavitsas, V.I. Flow perfusion improves seeding of tissue engineering scaffolds with different architectures. Ann Biomed Eng 35, 429, 2007.

68. Alvarez-Barreto, J.F., Landy, B., VanGordon, S., Place, L., DeAngelis, P.L., and Sikavitsas, V.I. Enhanced osteoblastic differentiation of mesenchymal stem cells seeded in RGD-functionalized PLLA scaffolds and cultured in a flow perfusion bioreactor. J Tissue Eng Regen Med 5, 464, 2011.

69. Bjerre, L., Bunger, C.E., Kassem, M., and Mygind, T. Flow perfusion culture of human mesenchymal stem cells on silicate-substituted tricalcium phosphate scaffolds. Biomaterials 29, 2616, 2008.

70. Braccini, A., Wendt, D., Jaquiery, C., Jakob, M., Heberer, M., Kenins, L., Wodnar-Filipowicz, A., Quarto, R., and Martin, I. Three-dimensional perfusion culture of human bone marrow cells and generation of osteoinductive grafts. Stem Cells 23, 1066, 2005.

71. Ma, T., Yang, S.T., and DA., K. Development of an in vitro human placenta model by the cultivation of human trophoblasts in a fiber-based bioreactor system. Tissue Eng 5, 91, 1999.

72. Zhao, F., Pathi, P., Grayson, W., Xing, Q., Locke, B.R., and $\mathrm{Ma}, \mathrm{T}$. Effects of oxygen transport on 3-D human mesenchymal stem cell metabolic activity in perfusion and static cultures: experiments and mathematical model. Biotechnol Prog 21, 1269, 2005.

73. Timmins, N.E., Scherberich, A., Fruh, J.A., Heberer, M., Martin, I., and Jakob, M. Three-dimensional cell culture and tissue engineering in a T-CUP (Tissue Culture Under Perfusion). Tissue Eng 13, 2021, 2007.

74. Costa, P.F., Martins, A., Neves, N.M., Gomes, M.E., and Reis, R.L. A novel bioreactor design for enhanced stem cells proliferation and differentiation in tissue engineered constructs. Tissue Eng Part A 14, 802, 2008.

75. Rodrigues, A.I., Gomes, M.E., Leonor, I.B., and Reis, R.L. Bioactive starch-based scaffolds and human adipose stem cells are a good combination for bone tissue engineering. Acta Biomater 8, 3765, 2012.

76. Du, D.J., Furukawa, K., and Ushida, T. Oscillatory perfusion seeding and culturing of osteoblast-like cells on porous beta-tricalcium phosphate scaffolds. $\underline{\text { J Biomed Mater Res }}$ Part A 86A, 796, 2008.

77. Kim, J.H., Lee, T.H., Song, Y.M., Kim, I.S., Cho, T.H., Hwang, S.J., and Kim, S.J. An implantable electrical bioreactor for enhancement of cell viability. Conf Proc IEEE Eng Med Biol Soc 2011, 3601, 2011.

78. Yeatts, A.B., Geibel, E.M., Fears, F.F., and Fisher, J.P. Human mesenchymal stem cell position within scaffolds in- 
fluences cell fate during dynamic culture. Biotechnol Bioeng 109, 2381, 2012.

79. Knapp, Y., Deplano, V., and Bertrand, E. Flow dynamics characterisation of a novel perfusion-type bioreactor for bone tissue engineering. Comput Methods Biomech Biomed Eng 15, 116, 2012.

80. Fan, J., Jia, X., Huang, Y., Fu, B.M., and Fan, Y. Greater scaffold permeability promotes growth of osteoblastic cells in a perfused bioreactor. J Tissue Eng Regen Med Jan 2013. [Epub ahead of print]; DOI: 10.1002/term.

81. Qian, X., Yuan, F., Zhimin, Z., and Anchun, M. Dynamic perfusion bioreactor system for 3D culture of rat bone marrow mesenchymal stem cells on nanohydroxyapatite/ polyamide 66 scaffold in vitro. J Biomed Mater Res Part B Appl Biomater 101, 893, 2013, [Epub ahead of print].

82. Nishi, M., Matsumoto, R., Dong, J., and Uemura, T. Engineered bone tissue associated with vascularization utilizing a rotating wall vessel bioreactor. I Biomed Mater Res Part A 101A, 421, 2013.

83. Porter, B.D., Lin, A.S., Peister, A., Hutmacher, D., and Guldberg, R.E. Noninvasive image analysis of 3D construct mineralization in a perfusion bioreactor. Biomaterials 28, 2525, 2007.

84. Volkmer, E., Drosse, I., Otto, S., Stangelmayer, A., Stengele, M., Kallukalam, B.C., Mutschler, W., and Schieker, M. Hypoxia in static and dynamic 3D culture systems for tissue engineering of bone. Tissue Eng Part A 14, 1331, 2008.

85. Kim, J., and Ma, T. Perfusion regulation of hMSC microenvironment and osteogenic differentiation in 3D scaffold. Biotechnol Bioeng 109, 252, 2012.

86. Hosseinkhani, H., Inatsugu, Y., Hiraoka, Y., Inoue, S., Shimokawa, H., and Tabata, Y. Impregnation of plasmid DNA into three-dimensional scaffolds and medium perfusion enhance in vitro DNA expression of mesenchymal stem cells. Tissue Eng 11, 1459, 2005.

87. Hosseinkhani, H., Hosseinkhani, M., Tian, F., Kobayashi, $\mathrm{H}$., and Tabata, Y. Ectopic bone formation in collagen sponge self-assembled peptide-amphiphile nanofibers hybrid scaffold in a perfusion culture bioreactor. Biomaterials 27, 5089, 2006.

88. Xie, Y.Z., Hardouin, P., Zhu, Z.N., Tang, T.T., Dai, K.R., and $\mathrm{Lu}, \mathrm{J} . \mathrm{X}$. Three-dimensional flow perfusion culture system for stem cell proliferation inside the critical-size beta-tricalcium phosphate scaffold. Tissue Eng 12, 3535, 2006.

89. Janssen, F.W., van Dijkhuizen-Radersma, R., Van Oorschot, A., Oostra, J., de Bruijn, J.D., and Van Blitterswijk, C.A. Human tissue-engineered bone produced in clinically relevant amounts using a semi-automated perfusion bioreactor system: a preliminary study. J Tissue Eng Regen Med 4, $12,2010$.

90. Janssen, F.W., Hofland, I., van Oorschot, A., Oostra, J., Peters, H., and van Blitterswijk, C.A. Online measurement of oxygen consumption by goat bone marrow stromal cells in a combined cell-seeding and proliferation perfusion bioreactor. J Biomed Mater Res Part A 79A, 338, 2006.

91. Jaasma, M.J., Plunkett, N.A., and O'Brien, F.J. Design and validation of a dynamic flow perfusion bioreactor for use with compliant tissue engineering scaffolds. J Biotechnol 133, 490, 2008.

92. Keogh, M.B., Partap, S., Daly, J.S., and O’Brien, F.J. Three hours of perfusion culture prior to 28 days of static culture, enhances osteogenesis by human cells in a collagen GAG scaffold. Biotechnol and Bioeng 108, 1203, 2011.
93. Barthold, M., Majore, I., Fargali, S., Stahl, F., Schulz, R., Lose, S., Mayer, H., and Jager, V. 3D-cultivation and characterisation of osteogenic cells for the production of highly viable bone tissue implants. In: Godia, F.F., ed. Animal Cell Technology Meets Genomics. Dordrecht, Netherlands: Springer, 2005, p. 199.

94. Schliephake, H., Zghoul, N., Jager, V., van Griensven, M., Zeichen, J., Gelinsky, M., and Szubtarsky, N. Bone formation in trabecular bone cell seeded scaffolds used for reconstruction of the rat mandible. Int J Oral Maxillofac Surg 38, 166, 2009.

95. Yeatts, A.B., and Fisher, J.P. Tubular perfusion system for the long-term dynamic culture of human mesenchymal stem cells. Tissue Eng Part C Methods 17, 337, 2011.

96. Bertrand, D., Dominique, B.R., Karim, O., Mickael, D., Véronique, V., Morad, B., Christian O, P, H., and David, B. A perfusion bioreactor for engineering bone constructs: an in vitro and in vivo study. Tissue Eng Part C Methods 17, 505, 2011.

97. Gardel, L.S., Correia-Gomes, C., Serra, L.A., Gomes, M.E., and Reis, R.L. A novel bidirectional continuous perfusion bioreactor for the culture of large-sized bone tissue-engineered constructs. J Biomed Mater Res B Appl Biomater 2013. [Epub ahead of print]; DOI: 10.1002/jbm.b.32955.

98. Liebschner, M.A.K. Biomechanical considerations of animal models used in tissue engineering of bone. Biomaterials $\mathbf{2 5}$, 1697, 2004.

99. Egermann, M., Goldhahn, J., and Schneider, E. Animal models for fracture treatment in osteoporosis. Osteoporos 16, S129, 2005.

100. Davidson, M.K., Lindsey, J.R., and Davis, J.K. Requirements and selection of an animal model. Isr J Med Sci 23, 551, 1987.

101. Hazzard, D.G., Bronson, R.T., Mcclearn, G.E., and Strong, R. Selection of an appropriate animal-model to study aging processes with special emphasis on the use of rat strains. I Gerontology 47, B63, 1992.

102. Tseng, S.S., Lee, M.A., and Reddi, H. Nonunions and the potential of stem cells in fracture-healing. J Bone Joint Surg Am 90A, 92, 2008.

103. Reichert, J.C., Saifzadeh, S., Wullschleger, M.E., Epari, D.R., Schutz, M.A., Duda, G.N., Schell, H., van Griensven, M., Redl, H., and Hutmacher, D.W. The challenge of establishing preclinical models for segmental bone defect research. Biomaterials 30, 2149, 2009.

104. Reinwald, S., and Burr, D. Review of nonprimate, large animal models for osteoporosis research. J Bone Miner Res 23, 1353, 2008.

105. Muschler, G.F., Raut, V.P., Patterson, T.E., Wenke, J.C., and Hollinger, J.O. The design and use of animal models for translational research in bone tissue engineering and regenerative medicine. Tissue Eng Part B Rev 16, 123, 2010.

106. Aerssens, J., Boonen, S., Lowet, G., and Dequeker, J. Interspecies differences in bone composition, density, and quality: potential implications for in vivo bone research. Endocrinology 139, 663, 1998.

107. Thorwarth, M., Schultze-Mosgau, S., Kessler, P., Wiltfang, J., and Schlegel, K.A. Bone regeneration in osseous defects using a resorbable nanoparticular hydroxyapatite. J Oral Maxillofac Surg 63, 1626, 2005.

108. O’Loughlin, P.F., Morr, S., Bogunovic, L., Kim, A.D., Park, B., and Lane, J.M. Selection and development of preclinical models in fracture-healing research. J Bone Joint Surg Am Vol 90A, 79, 2008. 
109. Stevenson, S., Hohn, R.B., and Templeton, J.W. Effects of tissue antigen matching on the healing of fresh cancellous bone allografts in dogs. Am J Vet Res 44, 201, 1983.

110. Stevenson, $\mathrm{S}$. The immune-response to osteochondral allografts in dogs. J Bone Joint Surg Am 69A, 573, 1987.

111. Welter, J.F., Shaffer, J.W., Stevenson, S., Davy, D.T., Field, G.A., Klein, L., Li, X.Q., Zika, J.M., and Goldberg, V.M. Cyclosporin A and tissue antigen matching in bone transplantation. Fibular allografts studied in the dog. Acta Orthop Scand 61, 517, 1990.

112. Stevenson, S., Xiao, Q.L., and Martin, B. The fate of cancellous and cortical bone after transplantation of fresh and frozen tissue-antigen-matched and mismatched osteochondral allografts in dogs. J Bone Joint Surg Am 73A, $1143,1991$.

113. Bensusan, J.S., Davy, D.T., Goldberg, V.M., Shaffer, J.W., Stevenson, S., Klein, L., and Field, G. The effects of vascularity and cyclosporin A on the mechanical properties of canine fibular autografts. J Biomech 25, 415, 1992.

114. Stevenson, S., Shaffer, J.W., and Goldberg, V.M. The humoral response to vascular and nonvascular allografts of bone. Clin Orthop Relat Res 326, 86, 1996.

115. Zaucha, J.M., Zellmer, E., Georges, G., Little, M.T., Storb, R., Storer, B., and Torok-Storb, B. G-CSF-mobilized peripheral blood mononuclear cells added to marrow facilitates engraftment in nonmyeloablated canine recipients: CD3 cells are required. Biol Blood Marrow Transplant 7, 613, 2001.

116. Newman, E., Turner, A.S., and Wark, J.D. The potential of sheep for the study of osteopenia - current status and comparison with other animal-models. Bone 16, S277, 1995.

117. Taylor, W.R., Ehrig, R.M., Duda, G.N., Schell, H., Seebeck, P., and Heller, M.O. On the influence of soft tissue coverage in the determination of bone kinematics using skin markers. J Orthop Res 23, 726, 2005.

118. Taylor, W.R., Ehrig, R.M., Heller, M.O., Schell, H., Seebeck, P., and Duda, G.N. Tibio-femoral joint contact forces in sheep. J Biomech 39, 791, 2006.

119. Ravaglioli, A., Krajewski, A., Celotti, G.C., Piancastelli, A., Bacchini, B., Montanari, L., Zama, G., and Piombi, L. Mineral evolution of bone. Biomaterials 17, 617, 1996.

120. Anderson, M.L.C., Dhert, W.J.A., de Bruijn, J.D., Dalmeijer, R.A.J., Leenders, H., van Blitterswijk, C.A., and Verbout, A.J. Critical size defect in the goat's os ilium-A model to evaluate bone grafts and substitutes. Clin Orthop Relat Res 364, 231, 1999.

121. den Boer, F.C., Patka, P., Bakker, F.C., Wippermann, B.W., van Lingen, A., Vink, G.Q.M., Boshuizen, K., and Haarman, H.J.T.M. New segmental long bone defect model in sheep: quantitative analysis of healing with dual energy Xray absorptiometry. I Orthop Res 17, 654, 1999.

122. Turner, A.S. Experiences with sheep surgery: strengths and as an animal model for shoulder shortcomings. J Shoulder and Elbow Surg 16, 158s, 2007.

123. Martini, L., Fini, M., Giavaresi, G., and Giardino, R. Sheep model in orthopedic research: a literature review. Comp Med 51, 292, 2001.

124. Hillier, M.L., and Bell, L.S. Differentiating human bone from animal bone: a review of histological methods. I Forensic Sci 52, 249, 2007.

125. Leung, K.S., Siu, W.S., Cheung, N.M., Lui, P.Y., Chow, D.H.K., James, A., and Qin, L. Goats as an osteopenic animal model. J Bone Miner Res 16, 2348, 2001.
126. Qin, L., Mak, A.T.F., Cheng, C.W., Hung, L.K., and Chan, K.M. Histomorphological study on pattern of fluid movement in cortical bone in goats. Anat Rec 255, 380, 1999.

127. Spaargaren, D.H. Metabolic-rate and body-size-a new view on the surface law for basic metabolic-rate. Acta Biotheor 42, 263, 1994.

128. Niederauer, G.G., Slivka, M.A., Leatherbury, N.C., Korvick, D.L., Harroff Jr., H.H., Ehler, W.C., Dunn, C.J., and Kieswetter, K. Evaluation of multiphase implants for repair of focal osteochondral defects in goats. Biomaterials 21, 2561, 2000.

129. Zhu, L., Liu, W., Cui, L., and Cao, Y.L. Tissue-engineered bone repair of goat femur defects with osteogenically induced bone marrow stromal cells. Tissue Eng 12, 423, 2006.

130. Kruyt, M.C., Dhert, W.J.A., Oner, F.C., van Blitterswijk, C.A., Verbout, A.J., and Bruijn, J.D. Analysis of ectopic and orthotopic boneformation in cell-based tissue-engineeredconstructs in goats. Biomaterials 28, 1798, 2007.

131. Oliveira, J.M., Rodrigues, M.T., Silva, S.S., Malafaya, P.B., Gomes, M.E., Viegas, C.A., Dias, I.R., Azevedo, J.T., Mano, J.F., and Reis, R.L. Novel hydroxyapatite/chitosan bilayered scaffold for osteochondral tissue-engineering applications: scaffold design and its performance when seeded with goat bone marrow stromal cells. Biomaterials 27, 6123, 2006.

132. Gardel, L.S., Dias, A., Link, D.P., Serra, L.A., Gomes, M.E., and Reis, R.L. Development of an novel bidirectional continuous perfusion bioreactor (BCPB) for culturing cells in 3D scaffolds. Histol Histopathol Cell Mol Biol 26, 70, 2011.

133. Rodrigues, M.T., Gomes, M.E., Viegas, C.A., Azevedo, J.T., Dias, I.R., Guzon, F.M., and Reis, R.L. Tissue-engineered constructs based on SPCL scaffolds cultured with goat marrow cells: functionality in femoral defects. J Tissue Eng Regen Med 5, 41, 2011.

134. Rimondini, L., Nicoli-Aldini, N., Fini, M., Guzzardella, G., Tschon, M., and Giardino, R. In vivo experimental study on bone regeneration in critical bone defects using an injectable biodegradable PLA/PGA copolymer. Oral Surg Oral Med Oral Pathol Oral Radiol Endod 99, 148, 2005.

135. Cacchioli, A., Spaggiari, B., Ravanetti, F., Martini, F.M., Borghetti, P., and Gabbi, C. The critical sized bone defect: morphological study of bone healing. Ann Fac Medic Vet di Parma 26, 97, 2006.

136. Ben-David, D., Kizhner, T.A., Kohler, T., Müller, R., Livne. E and Srouji, S. Cell-scaffold transplant of hydrogel seeded with rat bone marrow progenitors for bone regeneration. I Craniomaxillofac Surg 39, 364, 2011.

137. Gugala, Z., and Gogolewski, S. Regeneration of segmental diaphyseal defects in sheep tibiae using resorbable polymeric membranes: a preliminary study. J OrthopTrauma 13, 187, 1999.

138. Lindsey, R.W., Gugala, Z., Milne, E., Sun, M., Gannon, F.H., and Latta, L.L. The efficacy of cylindrical titanium mesh cage for the reconstruction of a critical-size canine segmental femoral diaphyseal defect. J Orthop Res 24, 1438, 2006.

139. Gugala, Z., Lindsey, R.W., and Gogolewski, S. New approaches in the treatment of critical-size segmental defects in long bones. Macromol Symp 253, 147, 2007.

140. Berner, A., Reichert. J.C., Woodruff, M.A., Saifzadeh, S., Morris, A.J., Epari, D.R., Nerlich, M., Schuetz, M.A., and Hutmacher, D.W. Autologous vs. allogenic mesenchymal progenitor cells for the reconstruction of critical sized seg- 
mental tibial bone defects in aged sheep. Acta Biomater $\mathbf{9}$, 7874, 2013.

141. Rentsch, B., Bernhardt, R., Scharnweber, D., Schneiders, W., Rammelt, S., and Rentsch, C. Embroidered and surface coated polycaprolactone-co-lactide scaffolds: a potential graft for bone tissue engineering. Biomaterials 2, 158, 2012.

142. Kuttenberger, J.J., Stubinger, S., Waibel, A., Werner, M., Klasing, M., Ivanenko, M., Hering, P., Von Rechenberg, B., Sader, R., and Zeilhofer, H.F. Computer-guided CO2-laser osteotomy of the sheep tibia: technical prerequisites and first results. Photomed Laser Surg 26, 129, 2008.

143. Kuttenberger, J.J., Waibel, A., Stubinger, S., Werner, M., Klasing, M., Ivanenko, M., Hering, P., von Rechenberg, B., Sader, R., and Zeilhofer, H.F. Bone healing of the sheep tibia shaft after carbon dioxide laser osteotomy: histological results. Lasers in Med Sci 25, 239, 2010.

144. Blokhuis, T.J., Wippermann, B.W., den Boer, F.C., van Lingen, A., Patka, P., Bakker, F.C., and Haarman, H.J.T.M. Resorbable calcium phosphate particles as a carrier material for bone marrow in an ovine segmental defect. I Biomed Mater Res 51, 369, 2000.

145. Sciadini, M.F., and Johnson, K.D. Evaluation of recombinant human bone morphogenetic protein-2 as a bone-graft substitute in a canine segmental defect model. I Orthop Res 18, 289, 2000.

146. Cook, S.D., Salkeld, S.L., Patron, L.P., Sargent, M.C., and Rueger, D.C. Healing course of primate ulna segmental defects treated with osteogenic protein-1. J Invest Surg 15, 69, 2002.

147. den Boer, F.C., Wippermann, B.W., Blokhuis, T.J., Patka, P., Bakker, F.C., and Haarman, H.J.T.M. Healing of segmental bone defects with granular porous hydroxyapatite augmented with recombinant human osteogenic protein-1 or autologous bone marrow. J Orthop Res 21, 521, 2003.

148. Arinzeh, T.L., Peter, S.J., Archambault, M.P., van den Bos, C., Gordon, S., Kraus, K., Smith, A., and Kadiyala, S. Allogeneic mesenchymal stem cells regenerate bone in a critical-sized canine segmental defect. J Bone Joint Surg Am 85A, 1927, 2003.

149. Brodke, D., Pedrozo, H.A., Kapur, T.A., Attawia, M., Kraus, K.H., Holy, C.E., Kadiyala, S., and Bruder, S.P. Bone grafts prepared with selective cell retention technology heal canine segmental defects as effectively as autograft. I Orthop Res 24, 857, 2006.

150. Niemeyer, P., Schonberger, T.S., Hahn, J., Kasten, P., Fellenberg, J., Suedkamp, N., Mehlhorn, A.T., Milz, S., and Pearce, S. Xenogenic transplantation of human mesenchymal stem cells in a critical size defect of the sheep tibia for bone regeneration. Tissue Eng Part A 16, 33, 2010.

151. Bullens, P.H.J., Hannink, G., Verdonschot, N., and Buma, P. No effect of dynamic loading on bone graft healing in femoral segmental defect reconstructions in the goat. Injury 41, 1284, 2010.

152. Zhu, L., Chuanchang, D., Wei, L.Y., C., Jiasheng, D., and Lian, Z. Enhanced healing of goat femur-defect using BMP7 gene-modified BMSCs and load-bearing tissue-engineered bone. J Orthop Res 28, 412, 2010.

153. Viateau, V., Guillemin, G., Bousson, V., Oudina, K., Hannouche, D., Sedel, L., Logeart-Avramoglou, D., and Petite, $\mathrm{H}$. Long-bone critical-size defects treated with tissueengineered grafts: a study on sheep. J Orthop Res 25, 741, 2007.

154. Nair, M.B., Varma, H.K., Menon, K.V., Shenoy, S.J., and John, A. Reconstruction of goat femur segmental defects using triphasic ceramic-coated hydroxyapatite in combination with autologous cells and platelet-rich plasma. Acta Biomater 5, 1742, 2009.

155. Murakami, N., Saito, N., Horiuchi, H., Okada, T., Nozaki, K., and Takaoka, K. Repair of segmental defects in rabbit humeri with titanium fiber mesh cylinders containing recombinant human bone morphogenetic protein-2 (rhBMP2) and a synthetic polymer. J Biomed Mater Res 62, 169, 2002.

156. Vogelin, E., Jones, N.F., Huang, J.I., Brekke, J.H., and Lieberman, J.R. Healing of a critical-sized defect in the rat femur with use of a vascularized periosteal flap, a biodegradable matrix, and bone morphogenetic protein. J Bone Joint Surg Am 87A, 1323, 2005.

157. Cheng, M.H., Brey, E.M., Allori, A., Satterfield, W.C., Chang, D.W., Patrick, C.W., and Miller, M.J. Ovine model for engineering bone segments. Tissue Eng 11, 214, 2005.

158. Forriol, F., Denaro, L., Longo, U.G., Taira, H., Maffulli, N., and Denaro, V. Bone lengthening osteogenesis, a combination of intramembranous and endochondral ossification: an experimental study in sheep. Strategies Trauma Limb Reconstr 5, 71, 2010.

159. Horner, E.A., Kirkham, J., Wood, D., Curran, S., Smith, M., Thomson, B., and Yang, X.B.B. Long bone defect models for tissue engineering applications: criteria for choice. Tissue Eng Part B Rev 16, 263, 2010.

160. Einhorn, T.A. Clinically applied models of bone regeneration in tissue engineering research. Clin Orthop Relat Res 367 Suppl, S59, 1999.

161. Hansen, M., Mehler, D., Hessmann, M.H., Blum, J., and Rommens, P.M. Intramedullary stabilization of extraarticular proximal tibial fractures: a biomechanical comparison of intramedullary and extramedullary implants including a new Proximal Tibia Nail (PTN). J Orthop Trauma 21, 701, 2007.

162. Krettek, C., Schandelmaier, P., Miclau, T., and Tscherne, H. Minimally invasive percutaneous plate osteosynthesis (MIPPO) using the DCS in proximal and distal femoral fractures. Injury 28, Sa20, 1997.

163. Gao, T.J., Lindholm, T.S., Kommonen, B., Ragni, P., Paronzini, A., Lindholm, T.C., Jalovaara, P., and Urist, M.R. The use of a coral composite implant containing bone morphogenetic protein to repair a segmental tibial defect in sheep. Int Orthop 21, 194, 1997.

164. Kirker-Head, C.A., Gerhart, T.N., Armstrong, R., Schelling, S.H., and Carmel, L.A. Healing bone using recombinant human bone morphogenetic protein 2 and copolymer. Clin Orthop Relat Res 349, 205, 1998.

165. Wefer, J., Wefer, A., Schratt, H.E., Thermann, H., and Wippermann, B.W. Healing of autologous cancellous bone transplants and hydroxylapatite ceramics in tibial segment defects. Value of ultrasonic follow up. Unfall chirurg 103, $452,2000$.

166. Meinel, L., Zoidis, E., Zapf, J., Hassa, P., Hottiger, M.O., Auer, J.A., Schneider, R., Gander, B., Luginbuehl, V., Bettschart-Wolfisberger, R., Illi, O.E., Merkle, H.P., and von Rechenberg, B. Localized insulin-like growth factor I delivery to enhance new bone formation. Bone 33, 660, 2003.

167. Mastrogiacomo, M., Corsi, A., Francioso, E., Di Comite, M., Monetti, F., Scaglione, S., Favia, A., Crovace, A., Bianco, P., and Cancedda, R. Reconstruction of extensive long bone defects in sheep using resorbable bioceramics based on silicon stabilized tricalcium phosphate. Tissue Eng 12, 1261, 2006. 
168. Teixeira, C.R., Rahal, S.C., Volpi, R.S., Taga, R., Cestari, I.M., Granieiro, J.M., Vulcano, L.C., and Correa, M.A. Tibial segmental bone defect treated with bone plate and cage filled with either xenogeneic composite or autologous cortical bone graft. Vet Comp Orthop Traumatol 20, 269, 2007.

169. Klaue, K., Knothe, U., Anton, C., Pfluger, D.H., Stoddart, M., Masquelet, A.C., and Perren, S.M. Bone regeneration in long-bone defects: tissue compartmentalisation? In vivo study on bone defects in sheep. Injury 40, S95, 2009.

170. Bella, C.A., N.N. Lucarelli, E. Dozza, B. Frisoni, T. Martini, L. Fini, M., and Donati, D. Osteogenic protein-1 associated with mesenchymal stem cells promote bone allograft integration. Tissue Eng Part A 16, 2967, 2010.

171. Bloemers, F.W., Blokhuis, T.J., Patka, P., Bakker, F.C., Wippermann, B.W., and Haarman, H.J.T.M. Autologous bone versus calcium-phosphate ceramics in treatment of experimental bone defects. J Biomed Mater Res Part B 66B, 526, 2003.

172. Sarkar, M.R., Augat, P., Shefelbine, S.J., Schorlemmer, S., Huber-Lang, M., Claes, L., Kinzl, L., and Ignatius, A. Bone formation in a long bone defect model using a platelet-rich plasma-loaded collagen scaffold. Biomaterials 27, 1817, 2006.

173. Schneiders, W., Reinstorf, A., Biewener, A., Serra, A., Grass, R., Kinscher, M., Heineck, J., Rehberg, S., Zwipp, H., and Rammelt, S. In vivo effects of modification of hydroxyapatite/collagen composites with and without chondroitin sulphate on bone remodeling in the sheep tibia. J Orthop Res 27, 15, 2009.

174. van Loon, C.J., Buma, P., de Waal Malefijt, M.C., van Kampen, A., and Veth, R.P. Morselized bone allografting in revision total knee replacement-a case report with a 4year histological follow-up. Acta Orthop Scand 71, 98, 2000.

175. Wang, J.S., Tagil, M., and Aspenberg, P. Load-bearing increases new bone formation in impacted and morselized allografts. Clin Orthop Relat Res 378, 274, 2000.
176. van der Donk, S., Buma, P., Verdonschot, N., and Schreurs, B.W. Effect of load on the early incorporation of impacted morsellized allografts. Biomaterials 23, 297, 2002.

177. Field, J.R., Mcgee, M., Stanley, R., Ruthenbeck, G., Papadimitrakis, T., Zannettino, A., Gronthos, S., and Itescu, S. The efficacy of allogeneic mesenchymal precursor cells for the repair of an ovine tibial segmental defect. Vet Comp Orthop Traumatol 24, 113, 2011.

178. Gugala, Z., and Gogolewski, S. Healing of critical-size segmental bone defects in the sheep tibiae using bioresorbable polylactide membranes. Injury 33, 71, 2002.

179. Maissen, O., Eckhardt, C., Gogolewski, S., Glatt, M., Arvinte, T., Steiner, A., Rahn, B., and Schlegel, U. Mechanical and radiological assessment of the influence of rhTGF beta3 on bone regeneration in a segmental defect in the ovine tibia: pilot study. J Orthop Res 24, 1670, 2006.

180. Liu, G., Zhao, L., Zhang, W., Cui, L., Liu, W., and Cao, Y. Repair of goat tibial defects with bone marrow stromal cells and beta-tricalcium phosphate. J Mater Sci Mater Med 19, 2367, 2008.

Address correspondence to:

Leandro S. Gardel, DVM, PhD

3B'S Research Group

University of Minho

Headquarters of the European Institute of Excellence on Tissue Engineering and Regenerative Medicine

AvePark, Taipas

Guimarães 4806-909

Portugal

E-mail: lgardel@gmail.com

Received: January 11, 2013

Accepted: July 17, 2013

Online Publication Date: October 11, 2013 